\title{
UNIVERSIDADE DE SÃO PAULO ESCOLA DE ENFERMAGEM DE RIBEIRÃO PRETO DEPARTAMENTO DE ENFERMAGEM PSIQUIÁTRICA E CIÊNCIAS HUMANAS
}

\begin{abstract}
A TEORIA, A PERCEPÇÃO E A PRÁTICA DO RELACIONAMENTO INTERPESSOAL
\end{abstract}

Maria Inês Lemos Coelho Ribeiro

\author{
Ribeirão Preto - SP \\ 2005
}




\title{
A TEORIA, A PERCEPÇÃO E A PRÁTICA DO RELACIONAMENTO INTERPESSOAL
}

\author{
Maria Inês Lemos Coelho Ribeiro
}

Tese apresentada ao Programa de Pósgraduação em Enfermagem Psiquiátrica do Departamento de Enfermagem Psiquiátrica e Ciências Humanas da Escola de Enfermagem de Ribeirão Preto da Universidade de São Paulo.

Linha de Pesquisa: Educação em Saúde e Formação de Recursos Humanos.

Orientador: Prof. Dr. Luiz Jorge Pedrão

Ribeirão Preto - SP 2005 
Ribeiro, Maria Inês Lemos Coelho

A teoria, a percepção e a prática do relacionamento interpessoal.

Ribeirão Preto, 2005. 106p.

Tese de Doutorado, apresentada à Escola de Enfermagem de Ribeirão Preto/USP - Depto. Enfermagem Psiquiátrica.

Orientador: Pedrão, Luiz Jorge 


\title{
FOLHA DE APROVAÇÃO
}

\author{
Maria Inês Lemos Coelho Ribeiro
}

A teoria, a percepção e a prática do relacionamento interpessoal.

Tese apresentada ao Programa de Pósgraduação em Enfermagem Psiquiátrica do Departamento de Enfermagem Psiquiátrica e Ciências Humanas da Escola de Enfermagem de Ribeirão Preto da Universidade de São Paulo, para obtenção do Título de Doutor.

Aprovado em:

Banca Examinadora

Prof. Dr.

Instituição: Assinatura:

Prof. Dr.

Instituição: Assinatura:

Prof. Dr.

Instituição: Assinatura:

Prof. Dr.

Instituição: Assinatura:

Prof. Dr.

Instituição: Assinatura: 


\section{DEDICATÓRIA}

Ao José Luiz, Isabela e Camila, meu esposo e filhas, com amor, admiração e gratidão, pelo carinho, compreensão, ajuda e incentivo

À minha mãe Wilza, meus irmãos, Luiz Henrique, Sandra e Tânia pelo imenso carinho e apoio constante nesta minha caminhada

À vovó Nenza, por seu exemplo e orações que são essenciais em minha vida 


\section{AGRADECIMENTOS}

Ao professor doutor Luiz Jorge Pedrão, pela orientação, apoio e estímulo no desenvolvimento deste trabalho, na busca do saber e do conhecimento e pela amizade conquistada a cada dia...

Aos diretores e funcionários do CEFAN, especialmente Alessandra e Sabrina, pela disposição e gentileza em facilitar o desenvolvimento deste trabalho.

Às professoras Ana, Cila, Rosa e Evânia, pela disponibilidade, interesse e valiosas contribuições científicas que trouxeram para este estudo.

Às alunas do curso de Técnico em Enfermagem, Sirlene e Terezinha, pela ajuda e disponibilidade.

Às secretárias do Departamento de Enfermagem Psiquiátrica e Ciências Humanas da Escola de Enfermagem de Ribeirão Preto e da Pósgraduação, pela atenção prestada.

À Santa Casa de Misericórdia de Passos e ao Hospital Otto Krakauer por ter permitido a realização do presente trabalho. caminhada.

À Elexandra, Valisete e Raquel, amigas e companheiras nesta

À CAPES pelo apoio financeiro. 


\section{RESUMO}

RIBEIRO, M.I.L.C. A teoria, a percepção e a prática do relacionamento interpessoal. 2005. 106p. Tese Doutorado - Escola de Enfermagem de Ribeirão Preto, Universidade de São Paulo, Ribeirão Preto.

O presente estudo tem como objetivos investigar junto a pacientes de clínica médica, cirúrgica e psiquiátrica sua compreensão sobre Relacionamento Interpessoal, qual a importância desta habilidade, como ela ocorre entre os técnicos e auxiliares de enfermagem com os pacientes das referidas clínicas, o motivo que os levou a este relacionamento e a freqüência desta interação. A metodologia adotada foi a descritivo-exploratória na abordagem qualitativa. $\mathrm{O}$ estudo foi realizado em dois hospitais que atendem pacientes conveniados ao Sistema Único de Saúde (SUS), em Passos, Minas Gerais, sendo um hospital geral com clínicas médica e cirúrgica e o outro um hospital psiquiátrico. Fizeram parte do estudo oitenta e sete (87) pacientes dos quais quinze (15) foram submetidos à uma entrevista prévia e setenta e dois (72) foram observados por observadores treinados que a prática da habilidade descrita acima desenvolvida pelos técnicos e auxiliares de enfermagem referidos. Os resultados das entrevistas apresentaram a visão dos pacientes de como são tratados pelos técnicos e auxiliares de enfermagem que trabalham nos referidos hospitais, os conteúdos de suas conversas com esses profissionais, como essas conversas os ajudam, seus sentimentos, o que mais valorizam para o seu bem estar e suas sugestões para melhorar a assistência de enfermagem. Evidenciouse que apesar dos pacientes relatarem que são bem tratados, suas falas levam ao entendimento de que eles evitam fazer comentários negativos da assistência por medo de serem mal tratados e também por medo de ofender os profissionais. As conversas que ocorreram foram breves, superficiais e mecânicas. Constatou-se a predominância por parte dos técnicos e auxiliares de enfermagem em realizar as técnicas, deixando evidente sua formação instrumental, não sendo incluído nesta o relacionamento interpessoal como técnica. Ficou claro seu despreparo para se comunicarem ou se relacionarem com os pacientes, apesar desses relatarem que um dos fatores que mais influenciam em seu bem estar é o relacionamento interpessoal.

Palavra-chave: Relacionamento Interpessoal, Técnicos e Auxiliares de Enfermagem. 


\section{SUMMARY}

RIBEIRO, M.I.L.C. The theory, the feeling and the practicing of relationship. 2005. 106p. Doctorate Thesis - Nursing School of Ribeirão Preto, University of São Paulo, Ribeirão Preto.

The objective of this present study was to investigate the relationship among patients from medical, surgical and psychiatrist clinics, their understanding about this subject, what is the importance of this hability, how it happens between nursing technicians and nursing assistants and the patients from those clinics, the reason that these professionals decided to apply this relation and how often it has been applied. The metodology adopted was the exploratory descriptive with qualitative research. The study was performed in a psychiatrist hospital and in a hospital where there were medical and surgical clinics. Both of hospitals attend patients connected to Basic Heath Units, in Passos, Minas Gerais. 87 patients participated in this study, 15 of them were interviewed and 72 patients were observed by trained observers. The results of these interviews related what the patients really think about the way they are treated by the nursing technicians and the nursing assistants that work at those hospitals, and the content of their talks with those professionals, how these talks help them, their feelings, their well being and their suggestions to improve the nursing assistance. Even though the patients reported that they are well treated by the nursing technicians and the nursing assistants it was realized that they tend to avoid making negative comments about the assistance afraid of offending the professionals and being bad treated by them. The talks were brief, superficial and mechanic. It was showed the predominance / willingness of those nursing technicians and assistants in appling the technics, their instrumental formation clearly. Relationship was not include as a technic. What it was also clear was that they were not prepared to communicate or to have a relationship with those patients, even though the patients say relationship is one of the reasons that most brought them their well being.

Key - words: nursing technicians, nursing assistants 


\section{RESUMEN}

RIBEIRO, M.I.L.C. La teoria, la percepción y la práctica de la relación interpersonal. 2005. 106p. La tesis del doctorado- la Escuela de Enfermería de Ribeirão Preto, la Universidad de São Paulo, Ribeirão Preto.

El presente estudio tiene como objetivos investigar junto a pacientes de clínica médica, quirúrgica y psiquiátrica su comprensión sobre Relación Interpersonal, cual la importancia de esta habilidad, como ella ocurre entre los técnicos y auxiliares de enfermería con los pacientes de las referidas clínicas, el motivo que los llevó a esta relación y la frecuencia de esta interacción. La metodología adoptada fue el descriptivo exploratorio en el abordaje cualitativo. El estudio fue realizado en dos hospitales que atienden pacientes del convenio del Sistema Único de Salud (SUS), en Passos, Minas Gerais, siendo un hospital general con clínicas médica y quirúrgica y el otro un hospital psiquiátrico. Formaron parte del estudio ochenta y siete (87) pacientes de los cuáles quince (15) fueron sometidos a la una entrevista previa y setenta y dos (72) fueron observados por observadores entrenados que la práctica de la habilidad descrita arriba desarrollada por los técnicos y auxiliares de enfermería referidos. Los resultados de las entrevistas presentaron la visión de los pacientes de como son tratados por los técnicos y auxiliares de enfermería que trabajan en los referidos hospitales, los contenidos de sus conversaciones con esos profesionales, como esas conversaciones los ayudan, sus sentimientos, lo que más valoran para su solaz y sus sugerencias para mejorar la asistencia de enfermería. Se evidenció que a pesar de los pacientes que relaten que son bien tratados, sus hablas llevan a la comprensión de que ellos evitan hacer comentarios negativos de la asistencia por miedo de que tengan mal tratos y también por miedo de ofender los profesionales. Las conversaciones que ocurrieron fueron breves, superficiales y mecánicas. Se constató la predominancia por parte de los técnicos y auxiliares de enfermería en realizar las técnicas, dejando evidente su formación instrumental, no siendo incluido en esta la relación interpersonal como técnica. Se quedó claro su no preparo para que se comuniquen o que se relacionen con los pacientes, a pesar de esos que relaten que uno de los factores que más influencian en su solaz es la relación interpersonal.

La palabra importante: La relación Interpersonal, Técnicos y Auxiliares de Enfermería. 


\section{LISTA DE QUADROS}

Quadro 1 Visão dos pacientes de como são tratados pelas pessoas que trabalham no hospital.

Quadro 2 Categoria 1- Percepção dos pacientes de como são tratados.

Quadro 3 Respostas dos pacientes sobre os conteúdos das conversas com os técnicos e auxiliares de enfermagem e as situações em que elas ocorrem .

Quadro 4 Categoria 2- Conteúdo e circunstâncias da interação

Quadro 5 Respostas dos pacientes de como são tratados pelos técnicos e auxiliares de enfermagem.

Quadro 6 Categoria 3- Percepção do tratamento oferecido pelos técnicos e auxiliares de enfermagem.

Quadro 7 Respostas dos pacientes de como a conversa ajuda no seu tratamento.

Quadro 8 Categoria 4- Contribuições das conversas no tratamento.

Quadro 9 Respostas dos pacientes sobre como eles se sentem quando técnicos ou auxiliares de enfermagem conversam com eles.

Quadro 10 Categoria 5 - Sentimentos do paciente frente à comunicação com os técnicos e auxiliares de enfermagem.

Quadro 11 O que os pacientes mais valorizam para o seu bem estar.

Quadro 12 Categoria 6 - Aspectos que contribuem para o bem estar do paciente.

Quadro 13 Sugestões dos pacientes para melhorar assistência de 68 enfermagem.

Quadro 14 Categoria 7 - Sugestões destacadas para melhorar a assistência de enfermagem.

Quadro 15 Síntese das observações realizadas na clínica médica.

Quadro 16 Síntese das observações realizadas na clínica cirúrgica.

Quadro 17 Síntese das observações realizadas na clínica psiquiátrica. 


\section{SUMÁRIO}

1. INTRODUÇÃO 01

2. O ENSINO DO RELACIONAMENTO INTERPESSOAL NO NÍVEL MÉDIO DE ENFERMAGEM, SUA IMPORTÂNCIA E SUA APLICABI LIDADE

3. MODELOS BÁSICOS DE ASSISTÊNCIA EM SAÚDE MENTAL 28

3.1 MODELO MÉDICO 29

3.2 MODELO COMPORTAMENTAL 30

3.3 MODELO PSICODINÂMICO 30

3.4 MODELO PREVENTIVISTA 32

3.5 MODELO SOCIAL 33

3.6 MODELO EXISTENCIAL 33

3.7 MODELO COGNITIVO 34

3.8 MODELO HOLÍSTICO 35

3.9 MODELO HUMANISTA OU INTERPESSOAL 35

4. OBJETIVOS 39

5. TRAJETÓRIA METODOLÓGICA 40

5.1 CARACTERÍSTICAS DO ESTUDO 40

5.2 CONTEXTO DO ESTUDO 41

5.3 PARTICIPANTES DO ESTUDO 42

5.4 PROCEDIMENTOS ÉTICOS 43

5.5 PROCEDIMENTOS PARA COLETA DE DADOS 44

5.6 PROCEDIMENTOS PARA ANÁLISE DOS DADOS 48

6. RESULTADOS E DISCUSSÃO 50

7. CONCLUSÕES

8. REFLEXÕES FINAIS 93

9. REFERÊNCIAS BIBLIOGRÁFICAS 96

10 APÊNDICES 102

$\begin{array}{ll}\text { 11. ANEXO } & 105\end{array}$ 


\section{INTRODUÇÃO}

A equipe de saúde cada vez mais vem mostrando a sua necessidade de aprimoramento e seu desempenho é alvo de estudo. Para alcançar o sucesso na assistência ao paciente, sua busca pelo aperfeiçoamento do cuidado prestado vem se tornando uma constante em diversas unidades assistenciais.

Essa preocupação deveria estar presente na prestação do cuidado em todas as instituições de assistência à saúde, sejam elas públicas, privadas, ou de ensino. Devido a complexidade do assunto e a importância que tem na qualidade da assistência, faz-se necessário o desenvolvimento de estudos buscando maior aproximação dessa temática.

O saber em enfermagem vem ganhando espaço, sendo este constituído pelo conhecimento, instrumentos e condutas e pelas relações sociais, tornando-se a base para o cuidado de enfermagem (SILVA, 1999). Matos (1995), descreve que espera-se um “equilíbrio dinâmico e dialético entre a teoria e a prática. A teoria dá forma à prática e esta, por sua vez, questiona a teoria”. A busca de enfermeiros através de pesquisas envolvendo a questão das relações interpessoais na prática do 
cuidado para além da técnica, mostra a crescente preocupação com a qualidade da assistência, voltada a cuidados individualizados e de forma integral.

Sabe-se que a qualificação profissional e a formação em serviço ocupam lugar de destaque no mercado de trabalho. Nesse sentido, dentre as funções sociais prioritárias exercidas pela educação, emerge a necessidade de atuação na formação de cidadãos capazes de atender as exigências que estão sendo postas. Diante das novas exigências, discute-se a formação e a qualificação técnico-profissional, não como uma alternativa para o sistema educacional básico e de nível médio, mas como um complemento deste. As relações profissionais e as condições de trabalho vivenciadas pelo nível médio têm forte influência em sua prática o que muitas vezes provoca um distanciamento entre a aprendizagem durante o ensino e sua execução na prática, além de enfatizar que as influências do curso sobre a formação e atuação dos profissionais de nível médio de enfermagem são vistas por ele como significativas para seu crescimento como pessoa e cidadão (STUTZ, 1999).

No trabalho realizado por Santiago, Lopes \& Caldas (2002) em que os autores fizeram uma revisão da produção científica dos enfermeiros sobre Educação em Enfermagem, observa-se que nos vários temas abordados estes se voltam para a promoção, aperfeiçoamento, atualização e ampliação do saber, contribuindo assim para melhor desempenho e competência, tendo como atenção a atualização no processo de globalização e dos avanços tecnológicos.

Souza (1997) escreve que o enfermeiro é um dos componentes fundamentais para a melhoria da prática assistencial e que também contribuiu, de fato, para uma conquista da profissionalização em Enfermagem, sendo responsável 
pela formação, educação permanente e capacitação de sua equipe, tornando-o um agente transformador da realidade.

O mercado de trabalho busca profissionais versáteis, com capacidade de decisão, senso de responsabilidade, autonomia, autoconfiança, espírito crítico, cooperação e capacidade de comunicação. Isto leva a reflexões sobre mudanças que apontam para novos rumos da educação (MACHADO, TAKAMATSU \& FILOCRE, 1998).

Acredita-se que a valorização da dignidade humana, a afeição, o compromisso com o desenvolvimento do homem, e os princípios éticos, são as luzes para o desenvolvimento de um método e uma tecnologia humanística aplicadas ao cuidado. Essas luzes proporcionam a ampliação e otimização do conhecimento científico e tecnológico e poderão viabilizar o salto qualitativo da Enfermagem e a valorização cada vez maior das relações e do cuidado humano no terceiro milênio (WOLFF, GONÇALVES \& YEDE, 1998).

De acordo com Cadah (2000) a equipe de enfermagem representa o maior grupo que tem contato com o paciente; portanto os pacientes, com freqüência julgam as organizações pela qualidade do serviço de enfermagem. Diversos trabalhos têm sido desenvolvidos relacionados à avaliação da assistência de enfermagem em instituições de saúde. Nestes, pode-se observar que a avaliação da qualidade da assistência implica numa abordagem sistemática dos cuidados prestados.

Na saúde, a qualidade vem sofrendo várias alterações ao longo dos anos; antes era medida pelos índices de mortalidade, morbidade e tempo de permanência no hospital. Hoje, são adotadas outras medidas de resultados relativos ao estado do paciente, como: condições funcionais de saúde; indicadores psicológicos, incluindo o 
bem estar, a auto-estima e o domínio do comportamento; aplicação de conhecimento; motivação e até a satisfação do paciente.

A qualidade em saúde é ressaltada no cuidado, é o que maximiza o bem estar do paciente. Portanto, a satisfação total poderia ser avaliada como uma soma dos aspectos de tratamento técnico, das características da atenção interpessoal e as conseqüências fisiológicas, psicológicas e sociais.

Outro aspecto a ser considerado é que vários autores como Bittes Júnior (1996), Cadah (2000), Piagge (1998) entre outros, destacam que a moderna teoria da qualidade é centrada no paciente, focalizando assim a satisfação e as expectativas deste. Portanto, coordenar os cuidados para atender a estas expectativas permitirá à equipe de enfermagem obter sucesso na melhoria da qualidade de assistência percebida pelo paciente e familiares.

Martins (1996), escreve que atualmente existe um crescente empenho dos profissionais e instituições de saúde em aperfeiçoar a qualidade dos serviços prestados à comunidade, tendo ocorrido gradativamente a incorporação de noções vinculadas à cidadania, direitos dos usuários e à responsabilidade ética dos profissionais no campo da assistência à saúde.

São os pacientes e seus familiares que melhor avaliam os cuidados recebidos, e assim, se tornam os melhores avaliadores da qualidade destes cuidados. O paciente destaca que o foco principal de sua avaliação não costuma ser a parte técnica e sim a humana, estando relacionado à simpatia, paciência, respeito e atenção. Assim é necessário estabelecer este relacionamento interpessoal com o cuidador, pois, quanto mais atender às suas perspectivas de cuidado, mais ele se sentirá cuidado e mais satisfeito ficará. 
Entende-se que o ponto de partida para verificação das expectativas do cliente é saber ouví-lo. Sendo assim, o enfermeiro necessita desenvolver competência específica para conhecer o paciente, e é importante desenvolver suas habilidades de comunicação e relacionamento interpessoal para também orientar a equipe de enfermagem nestas habilidades.

O desenvolvimento dessas habilidades, em especial a percepção da atenção e cortesia envolvida no relacionamento são fundamentais para o sucesso dos processos de qualidade em relação à satisfação do paciente.

Acredita-se que a melhor forma para que os profissionais de enfermagem se aproximem do paciente é a prática da empatia, pois esta prática implicará numa revisão dos próprios valores do enfermeiro, levando em consideração o esquema de valores do outro.

Embora os pacientes busquem cada vez mais uma atenção carinhosa e sensível, as exigências comerciais têm levado os profissionais de saúde à uma atenção pouco humana; mesmo sabendo que o atendimento das necessidades emocionais do paciente o levam a ter uma cura mais rápida e o deixa mais satisfeito.

Cadah (2000) cita estudos que mostram a diferença de visão de qualidade do cuidado de enfermagem entre os enfermeiros e pacientes. Os profissionais vêem a competência dos cuidados técnicos como qualidade da assistência, enquanto os pacientes percebem a qualidade desta como os cuidados decorrentes do relacionamento interpessoal.

Pode-se dizer que a eficiência e a produtividade de um grupo estão estreitamente relacionadas não somente com a competência, mas também com a dinâmica das relações interpessoais, com o seu grau de interação, com influências 
políticas e sociais. Essa integração da equipe leva ao envolvimento, compromisso das pessoas em que sentimentos e emoções são considerado no processo de trabalho, pois, a medida que estes fatores são ignorados, a tarefa passa a ser executada mecanicamente, automaticamente, sem motivação e assim diminuindo a sua qualidade (FERRAZ, 1982).

Sabe-se que o paciente faz parte do processo do cuidado, o qual está estreitamente ligado ao sucesso das ações de enfermagem. É importante ouvir e atender as pessoas envolvidas neste processo, que usufruem dos serviços de saúde. Atualmente, tem-se observado que o paciente tem conquistado maior espaço na busca de seus direitos e a evidência disto é a utilização do Código de Defesa do Consumidor. Também, constata-se, a importância do paciente através de citações do Código de Ética dos Profissionais de Enfermagem, declarando ter o cliente/paciente o direito de decidir sobre seu tratamento e seu bem estar (MATSUDA, ÉVORA \& BOAN, 2000).

Os enfermeiros atribuem ao paciente um significado predominantemente técnico quando se referem a ele como um doente que exige cuidados, recursos humanos e tecnológicos e, ao mesmo tempo, categorizando-o como um ser dependente, instável biologicamente, cheio de tubos, sangramentos e feridas. Por outro lado, e contraditoriamente, também lhes atribuem a condição de pessoa ou de Ser Humano ao reportarem suas dificuldades às características de ordem humana, por meio de emoções como o medo, a ansiedade, a preocupação e, principalmente, a falta da família. Acreditam que o bem-estar, para ele, esteja ligado à perspectiva humana, quais sejam: estar ao lado da família, sentir-se o mais próximo possível de sua vida normal e cotidiana e, ainda, a certeza de estar sendo cuidado por outro Ser Humano. 
Portanto, além de perceber o bem-estar do paciente, através de indicadores humanos, como um olhar ou uma expressão facial, possui outras atitudes humanas ao respeitar a privacidade e a individualidade do paciente, aproximar-se dele, conversar buscando pontos em comum, com o intuito de proporcionar o seu bem estar (PIAGGE,1998).

Espera-se que seja incorporado, no meio acadêmico, o sentir e não apenas o saber. Afinal para ser enfermeiro (“cuidador”) não é necessário, apenas, saber: saber tudo, saber sempre, saber melhor, mas, conforme destaca Piagge (1998), é absolutamente necessário e a todo instante: ser disponível, ser pessoa, ser humano.

Assim, reforçando os aspectos discorridos acima Bittes Júnior (1996, p.37), relata que

"Via de regra, à medida em que o paciente percebe ou sente alguma necessidade que não consegue atender, seja para alimentar-se ou para trocar curativos, ele chama, solicita a presença daquele que pode ajudá-lo mas, não somente quando tem necessidades físicas; as necessidades sociais e emocionais também passam pelo mesmo processo. Chamei de necessidades emocionais, as necessidades em que os entrevistados demonstravam necessitar mais do que de um simples procedimento. $O$ que eles pareciam identificar como necessário, era a presença do outro, para se sentirem seguros $e$ acompanhados. Como alguns não dispunham de familiares acompanhantes, requisitavam os cuidadores do hospital, chegando a achar que o atendimento desta necessidade colaborava com sua tranqüilidade $e$ segurança em relação à sua recuperação".

O paciente cria uma expectativa de ser bem atendido quando está internado e entende que este atendimento, quando bom, tem semelhança com o cuidado que receberia de familiares, sendo a qualidade da relação entre cuidador/cuidado a garantia do sentir-se cuidado. Mesmo em instituição com número restrito de cuidadores, há o destaque para o relacionamento que diz respeito a ambas 
as partes, mas de iniciativa do profissional, mesmo porque este comportamento diz respeito as suas ações profissionais, e, quando bem aplicado, leva o paciente a uma satisfação e segurança, culminando em uma sensação de acolhimento e de melhora (BITTES JÚNIOR, 1996).

O amor e carinho são necessários para que os cuidados sejam feitos de maneira adequada proporcionando assim consideração pela pessoa cuidada e sucesso em sua ação, denotando-se compromisso e envolvimento com a ação cuidativa. Além disso, percebem-se as técnicas de enfermagem e as ações cuidativas, na maioria das vezes, como influências positivas à sua recuperação, perceptível na valorização das atividades e levantado pelos pacientes como premissas básicas e requisitos relevantes para sentirem-se cuidados, evidenciando o valor que o paciente dá ao relacionamento interpessoal. Por outro lado, relata-se também, que a pressa, a falta de paciência e atenção, levam o profissional a executar um cuidado desqualificado, e que,

"O paciente quer estabelecer um
relacionamento com um cuidador que tenha
amor e carinho por ele, paciente, e por sua
profissão, que seja uma pessoa que tenha
paciência, que dá orientações e
informações, que faça perguntas para
levantar suas necessidades e para saber
como está e que execute técnicas e ações
cuidativas que o levarão a ter emoções e
sentimentos positivos por estar
recuperando sua autonomia e recuperando
sua vida” (BITTES JÚNIOR, 1996, p.82-
3).

De acordo com Piagge (1998) os enfermeiros expressam o desejo de efetuar, em seu cotidiano de trabalho, algumas mudanças, sendo a maioria delas voltadas para o aspecto relacional e humano. A satisfação no trabalho está ligada a 
fatos técnicos, como o bom planejamento e andamento do plantão e a estabilidade e a melhoria das condições do paciente como resultado da intervenção do enfermeiro.

Bettinelli, Waskievicz \& Erdmann (2003) relatam sobre a humanização das relações e do cuidado ao ser humano como uma preocupação dos profissionais de saúde, compreendendo que neste deva estar incluido as atribuições técnicas e a capacidade de perceber e compreender a identidade de cada ser humano. Afirmam que freqüentemente convivemos em ambientes pouco humanizados, cujo funcionamento se restringe às técnicas, cujo centro da atenção é a “doença” e as pessoas são transformadas em objetos de trabalho. Entendem que o processo de cuidado precisa ocorrer numa relação, onde ocorre troca de informações, compromisso ético, participação ativa do paciente com seus valores morais e pessoais. Propõem que o cotidiano do cuidado passe por transformações efetivas em sua prática, que os profissionais de saúde ampliem sua compreensão, resgatem seus princípios e valores éticos para melhor convivência tanto na equipe multiprofissional como entre essa e o paciente. Ainda complementando relatam que o grande desafio dos profissionais de saúde é cuidar do ser humano nas dimensões física, psíquica, social e espiritual, com competência tecnocientífica e humana.

Segundo Miranda, Rodrigues \& Scatena (1996) o enfermeiro apreende o paciente como objeto de seu controle, passível de sua intervenção, dependência e de dominação, ignorando suas necessidades emocionais. Por outro lado, os enfermeiros que estão preocupados em assistir de forma mais humana sentem-se despreparados e inseguros para este relacionamento. Quando se propõe refletir sobre a prática profissional, sobre os atos e sobre a forma com que se relaciona com o paciente, se exerce uma atitude de saúde mental e também de saúde social. 
Boff (1999) escreve que o cuidado humano deve ser baseado na relação sujeito-sujeito e não sujeito-objeto, valorizando seus valores, de intensa convivência e nunca de intervenção, proporcionando assim interação entre ambos.

Entende-se que o Relacionamento Interpessoal seja essencial na prestação de cuidados aos usuários dos serviços de saúde e que este aparece como mola propulsora do cuidado humano na enfermagem.

Sempre a convivência humana tem sido difícil e desafiante, com interferências ou reações, voluntárias ou involuntárias, intencionais ou não, constituindo o processo de interação humana. Este processo é complexo e ocorre permanentemente com pessoas, sob a forma de comportamentos manifestos ou não, verbais ou não, pensamentos, sentimentos, reações mentais e ou físico-corporais (SOUZA, 1990).

Capra apud Madeira et al. (1996) afirma que hoje se pensa, fundamentado na abordagem holística, a qual preconiza a visão do ser humano na sua totalidade, se interrelacionando e em interdependência com todos os fenômenos, nos aspectos físicos, psicológicos, biológicos, sociais e culturais. Nessa proposta, considera-se o homem como constituído de corpo, mente e espírito em harmonia e integração com o meio. Portanto, é necessário ver o trabalhador de forma global, corpo, mente e espírito, participando e interagindo no seu ambiente de trabalho, interrelacionando-se com a natureza, com as pessoas e em constante busca pelo seu crescimento.

Rogers \& Rosenberg (1977) comentam que se podem utilizar os conhecimentos sobre o comportamento do homem nas suas relações cotidianas, escravizando as pessoas, despersonalizando-as, controlando-as, sem que elas tenham 
consciência disso, pode-se também fazer homens felizes, bem comportados e produtivos, obedecendo a um programa pré-preparado e traçado para que as pessoas possam segui-lo. Outra forma seria libertar as pessoas para desenvolverem a criatividade, ajudá-las a serem elas próprias, tendo condições para criar adaptações, dinamicamente, em suas vidas.

A teoria de Rogers (1978) dá ênfase às relações interpessoais e ao crescimento que delas resulta e que estas facilitam a aprendizagem, permitindo que as pessoas assumam o encargo de seguir novas direções de acordo com seus interesses, desencadeando o senso de pesquisa, indagação e análise, reconhecendo que tudo se acha em processo de mudança.

Aquino (2000) afirma que todas as atividades humanas estão baseadas no relacionamento interpessoal, sendo isso imperioso para que todas as pessoas possam conviver satisfatoriamente, pois o ser humano vive em grupo e, portanto, tem necessidade primária de relacionar-se com o outro, ou seja, na família, na escola ou no trabalho.

A enfermagem é uma profissão que lida com o ser humano, interage com ele e requer o conhecimento de sua natureza física, social, psicológica e suas aspirações espirituais. A relação com o outro ser envolve sentimentos ao cuidar e, portanto, ao se relacionar com o outro, dispõe-se a conhecê-lo (WALDOW, 1998).

O que qualifica a enfermagem é o seu caráter relacional, conforme atestam algumas teorias clássicas da enfermagem. Apesar desse enfoque, na relação afetiva com o paciente, a prática mostra-se contraditória, sendo estes muitas vezes tratados com indiferença pela equipe de enfermagem (PIAGGE, 1998). 
Americanas como Peplau (1952) e Travelbee (1982) estudaram e se dedicaram ao tema "Relacionamento Interpessoal”, referindo-se com profundidade aos princípios humanísticos, inerentes à abordagem da relação de pessoa a pessoa, o que inicialmente parece bastante rotineiro e familiar, no nosso campo de atuação. O relacionamento interpessoal, aparentemente muito simples, é de grande complexidade visto que são pessoas em interação, cada uma com suas características pessoais, sociais e culturais (RIBEIRO et al., 2003).

Destacando o papel do enfermeiro no processo de cuidar, Travelbee (1982) considera que ele pode ser o agente responsável em promover o relacionamento entre os componentes da equipe de trabalho, para que os mesmos possam respeitar o paciente como ser humano único. O privilégio de uma relação de pessoa a pessoa é de todos: paciente, enfermeiro, técnicos e auxiliares de enfermagem e os demais membros da equipe.

A teoria de Peplau (1952) se baseia nas relações enfermeiro-paciente e descreve a enfermagem como um processo interpessoal terapêutico, onde o processo de cuidar do paciente encerra um aspecto profissional, a relação enfermeiro-paciente, ou seja, o enfermeiro precisa reconhecer, definir e compreender o que acontece e quando ocorre relações com o paciente. Para ajudar um paciente é necessário compreender como ambos podem perceber a si mesmo, ao outro e a cada situação. A autora destaca que falar com o paciente é fácil quando não há preocupações com os efeitos de nossas palavras e ações sobre o comportamento deste. Portanto, a interação só se torna efetiva e terapêutica quando o enfermeiro está consciente de sua comunicação e assume responsabilidade sobre esta. 
Para Rodrigues (1991) o relacionamento enfermeiro-paciente é uma relação entre o profissional e a pessoa que requer ajuda, sendo que esta relação se dá através de um processo terapêutico, com início, meio e final, objetivando a resolução do problema. O sujeito não é tratado como objeto nem do conhecimento nem da ação, mas como alguém que enfrenta dificuldades. Considera que toda pessoa possui uma tendência positiva no sentido de se reorganizar, de se dirigir, de se preservar, o que o leva à busca do equilíbrio, do crescimento e do amadurecimento saudável.

O cuidado de enfermagem ocorre através das interações entre duas pessoas: uma que precisa de ajuda e outra que proporciona ajuda. A relação de ajuda é uma interação planejada, com objetivos definidos, na qual as pessoas que participam desta, modificam seu comportamento construtivamente com a evolução do processo de relacionamento. O enfermeiro se une ao paciente para ajudá-lo a revelar e compreender sua experiência, e, a partir daí, desenvolver um relacionamento, dando-lhe a oportunidade de observar sua própria experiência, analisar seus elementos, reconhecer o que está ocorrendo, expressar isto com outras pessoas através da comunicação e de examiná-la numa perspectiva adequada (TRAVELBEE 1982).

Avaliar seu desempenho durante o contato com a pessoa que requer ajuda é um hábito que a enfermagem não tem desenvolvido. Entretanto, este se reverte em inúmeras oportunidades para adequação do seu procedimento técnico tendo em vista as conseqüências benéficas para o outro (RIBEIRO et al., 2003).

O relacionamento interpessoal merece atenção especial pelo fato de que envolver duas personalidades distintas em interação, o que exige do profissional conhecimento específico. Cada interação é singular, não podendo ser repetida ou 
imitada. A relação enfermeira-paciente é uma experiência que se inicia de diferentes maneiras e que não se estabelece somente pela linguagem, mas por um conjunto de atitudes técnicas e afetivas. Toda interação tem um início, um desenvolvimento e um fim (GATTÁS, 1984).

As ações de cuidar propiciam que cuidadores e pacientes interajam, apesar destas parecerem se tornar cada vez mais impessoal, mecanizada e rotinizada, sendo comum o fato de muitos profissionais não saberem como iniciar ou manter uma conversação adequada com o paciente (RIBEIRO \& PEDRÃO, 2001).

Rudio (1990) enfatiza que o procedimento terapêutico diante da realidade do outro, não é de interpretar, avaliar ou julgar, mas de tentar compreender o que o outro está tentando comunicar com palavras, gestos e mímicas, buscando seu significado pessoal. As atitudes e os sentimentos do terapeuta são mais importantes do que a sua orientação teórica. Portanto, o exercício profissional deve ser humanizado para a melhoria da qualidade da assistência prestada com a obtenção de um nível ótimo de satisfação pessoal e profissional.

Todo o relacionamento interpessoal humanista consiste no ato de assistir ao ser humano, no seu processo vital, ajudando-o a aproximar-se de sua própria unicidade e singularidade. O ser humano necessita compreender-se melhor e ao outro, conscientizando-se de sua atuação no grupo, pois quando entendemos o outro e a nós mesmos, o relacionamento torna-se mais espontâneo e efetivo. As atividades humanas baseiam-se no relacionamento interpessoal e quando esse acontece no ambiente hospitalar, tende a ser mais difícil, em geral, pelo clima tenso que mobiliza ansiedade, devido a natureza das atividades que ali costumam ser desenvolvidas (AQUINO, 2000). 
Furegato (1999) escreve que se têm percebido que os enfermeiros de várias especialidades, originários de diferentes regiões do país, estão buscando algo mais do que simplesmente a execução de tarefas para atender às exigências de suas unidades. Eles querem tratar o paciente como ser humano e querem ser reconhecidos como seres humanos que ajudam os necessitados a terem uma vida melhor, apesar da doença ou do transtorno apresentado no momento. Ela enfatiza que o paciente é uma pessoa, um ser humano único, que no momento requer a ajuda profissional. O enfermeiro também é uma pessoa e um ser humano único, que adquiriu conhecimentos e habilidades específicas para cuidar dos outros e dispõe-se a isso, e, através da comunicação interpessoal, ambos poderão atingir seus objetivos.

A pessoa hospitalizada sofre um processo de despersonificação que, segundo Armelin \& Scatena (2000), deriva da fragmentação dos procedimentos, e o hospital, através de seus profissionais, pode ajudar as pessoas hospitalizadas a crescerem em direção à saúde, devendo, para isso, oferecer condições de promoção de bem estar físico, emocional e social.

Observa-se também, a despersonalização das pessoas agredindo o respeito pela dignidade dos doentes. O conceito de humanização aproxima-se do respeito. É necessário perceber o doente como único, insubstituível, e que merece ser tratado com dignidade. O respeito é o componente e o antecedente para cuidar e humanizar cuidados (CATARINO, CASSIANO \& SILVA, 1996).

Não se concebe prestar um cuidado de enfermagem mecanicamente, pois não se pode substituir nem o enfermeiro, nem os técnicos e auxiliares de enfermagem, nem o paciente por máquinas, que, ao contrário destas, as relações humanas são insubstituíveis. O contato com o paciente se dá quase sempre no 
desenvolvimento de algum procedimento, com raros momentos de comunicação e relacionamento, sendo que isto contribui para a visão do paciente e seus familiares de que a assistência de enfermagem é fria e desumana. Entende-se que um olhar, um toque ou um carinho associados a um procedimento técnico farão a diferença em uma prestação de cuidados. O paciente não evidencia quem executa melhor um procedimento, mas quem é mais gentil e atencioso para com ele (RIBEIRO \& FUREGATO, 2003).

Angerami \& Mendes (1988) salientam que os clientes requerem cuidados holísticos; a enfermagem atende-os através de uma prática fundamentada em conhecimentos científicos e valores humanísticos, pois ambos sustentam a ciência do cuidar, e "o cuidar é tido como um fenômeno social universal que só é efetivamente praticado de modo interpessoal”.

Segundo Lalanda (1995) importa olhar a prática dos cuidados como uma interação social, e refletir sobre essa interação é em parte se posicionar na estrutura existente. Isto leva a considerar a identidade profissional como uma reconstrução contínua, ou seja, refletir sobre o que se faz e como se faz, acaba por ser um ato de saúde mental e de saúde social.

Para Daniel (1981) o relacionamento deve ocorrer como um processo terapêutico de interação, afinidade, compreensão, aceitação entre os profissionais de enfermagem e o paciente por meio de conhecimento recíproco, o que possibilita uma assistência individualizada.

Uma boa comunicação também é importante para que possam ocorrer trocas de experiências entre a equipe de enfermagem, favorecendo o conhecimento mútuo, abordado nas relações interpessoais (KREUTZ, 1993). 
A comunicação é vista na enfermagem como um instrumento básico e também como uma competência do enfermeiro e uma habilidade a ser desenvolvida através do aprendizado da teoria da comunicação, técnicas e medidas de enfermagem (SADALA \& STEFANELLI, 1996). A comunicação interpessoal está dividida em verbal, associada à palavras e não-verbal que inclui as formas de comunicação que não envolvem as palavras, um olhar, um sorriso, um gesto ou até mesmo o silêncio (PEREIRA, 1999).

Por outro lado, não é possível existir equipe eficiente sem liderança. Para que esta ocorra são necessários dois fatores básicos: a coordenação por um enfermeiro, no planejamento, ministrando e avaliando a assistência individual; e a comunicação eficaz para garantir a continuidade da assistência (NAKAO, 1985). Acrescenta-se à estes fatores o relacionamento interpessoal entre os integrantes da equipe de enfermagem e os pacientes, para que a eficácia do trabalho de enfermagem seja garantido.

A comunicação é parte integrante do cuidar; portanto, é um instrumento de trabalho do enfermeiro e sua equipe, que precisa ser pesquisado para que seus resultados possam contribuir para os avanços esperados no campo da assistência à saúde (SOUZA, 1990).

Moscovici (1993) relata que competência interpessoal é a habilidade de lidar eficazmente com relações interpessoais, de lidar com outras pessoas de forma adequada às necessidades de cada um e às exigências da situação, e que o relacionamento interpessoal pode se tornar harmonioso trocando conhecimentos e experiências permitindo trabalho cooperativo e em equipe. 
Pereira (1999) salienta que nas relações interpessoais, a percepção do outro é um processo cognitivo no sentido de que cada um dos lados está percebendo e sendo percebido ao mesmo tempo, julgando e sendo julgado, informando e coletando informações para dar o próximo passo. No exercício da enfermagem, a comunicação é a base de sua existência, onde estão as relações humanas, com o paciente e com a equipe de trabalho.

A relação do homem com o trabalho e com as outras pessoas vem sendo muito discutida nos últimos anos pela necessidade que existe de torná-la mais harmoniosa e prazerosa. Moscovici (1993) demonstra em seus estudos que, para o ambiente de trabalho ser agradável e estimulante, é necessário que as relações interpessoais influenciem-no, e que essa influência seja uma meta a ser atingida por todos da organização.

Quando o enfermeiro mantém o grupo coeso, direcionado para o atendimento ao cliente, os conflitos existirão, mas o grupo terá condições de elaborar os conflitos e estes não serão suficientes para impedir que o grupo funcione. O relacionamento pessoal é algo difícil de entender e lidar, porém estabelecendo uma relação de coleguismo e confiança levará ao aproveitamento satisfatório de todos (ERDMANN \& PINHEIRO, 1998).

Embora a enfermagem psiquiátrica tenha se detido mais na consideração do relacionamento interpessoal, esta atitude profissional não é terreno exclusivo. Todo enfermeiro, seja ele generalista ou especialista, pode e deve introduzir tal relacionamento no seu dia-a-dia profissional. Esta é uma das formas de conservar a enfermagem na sua linha humanística, afastando-a do excesso de tecnicismo (GATTÁS, 1984). 
Cabe portanto, às instituições formadoras, proporcionar o desenvolvimento de habilidades e atitudes específicas, assim como oferecer conhecimentos a fim de que a enfermagem torne efetivas as relações terapêuticas através do relacionamento interpessoal (MIRANDA, RODRIGUES \& SCATENA, 1996).

Ao aprender técnicas sobre o relacionamento interpessoal, o estudante aprende sobre si mesmo à medida que começa a entender suas próprias reações a um comportamento e a empregar tais conhecimentos nos relacionamentos com seus colegas e pacientes, facilitando a compreensão mútua e aperfeiçoando as habilidades de comunicação. Estas habilidades precisam ser treinadas, praticadas e desenvolvidas para maior eficiência de resultados. Acredita-se que o conhecimento teórico das relações interpessoais pode ser adquirido através do ensino-aprendizagem e de educação continuada (SOUZA, 1990).

Segundo Bachion (1994), os docentes referem que o conteúdo de comunicação interpessoal é pequeno, e que são poucas as disciplinas que abordam este tema. Pode-se fazer uma analogia ao relacionamento interpessoal, quando os docentes desconsideram que este conteúdo faz parte de todas as disciplinas de um modo geral, já que as relações humanas se dão em qualquer especialidade da enfermagem.

A profissão de enfermagem, partindo de um relacionamento flexível e democrático, promoverá saúde mental, estimulando o desenvolvimento de personalidades sadias, substituindo práticas tradicionais que impedem o desempenho, como a velha e rígida disciplina, o tratamento frio e formal, por um relacionamento mais participante, mais humano. Enfim, urge que as variáveis relevantes e de 
controle no relacionamento enfermeiro-paciente sejam trabalhadas com mais atenção, porque é através do próprio relacionamento que podemos promover a saúde mental das pessoas (MANZOLLI, 1983).

Na visão de Gilioli (2000), para que a enfermagem seja ativa na sua própria humanização é necessário competência técnica, clareza política e estar centrada em valores como: respeito ao ser humano, solidariedade, honestidade, integridade, responsabilidade, cooperação, compreensão, prudência, interação, integração, disponibilidade, integrando dessa forma, o saber, o saber ser e o saber fazer.

No processo de cuidar, um aspecto relevante é a necessidade de se estabelecer uma relação interpessoal efetiva entre os técnicos e auxiliares de enfermagem e os pacientes, podendo tornar-se terapêutica, sendo capaz de repercutir positivamente na recuperação do bem estar e da saúde. Destacam-se várias questões que possam contribuir para o desenvolvimento desta postura profissional, como o estímulo e a reflexão do pensamento crítico, desde sua formação e até mesmo em atividades de educação continuada ao longo da atuação profissional (BECK, 1997). 


\section{O ENSINO DO RELACIONAMENTO INTERPESSOAL NO NÍVEL MÉDIO DE ENFERMAGEM, SUA IMPORTÂNCIA E SUA APLICABILIDADE}

É importante destacar que a compreensão sobre a abordagem do relacionamento interpessoal na formação de nível médio de enfermagem (técnicos e auxiliares) surgiu desde os estudos de graduação, seguiu-se na vivência hospitalar, exercendo funções de enfermeira supervisora, chefe de unidade e responsável por treinamento de pessoal. Atuando como docente em uma escola técnica observou-se que a formação oferecida aos auxiliares e técnicos em enfermagem é mais instrumental, ou seja, focaliza o aspecto físico, indicando cuidados para atendimento das necessidades do paciente, do que expressiva, que engloba o aspecto psicossocial. A inquietação sobre a assistência mais humanizada e a deficiência do relacionamento interpessoal motivou o aprofundamento deste tema no mestrado (RIBEIRO, 2002).

As observações anteriormente discorridas partiram do estudo de Ribeiro (2002) que investigou como os professores dos cursos de Técnicos e Auxiliares de Enfermagem abordavam o conteúdo do Relacionamento Interpessoal em suas disciplinas; a importância que era dada pelos alunos destes cursos a respeito do 
Relacionamento Interpessoal; e como os Auxiliares e Técnicos de Enfermagem estavam aplicando o conteúdo de Relacionamento Interpessoal, aprendido durante sua formação, em suas atividades profissionais. Os sujeitos do estudo foram 14 docentes do nível médio de enfermagem do Centro de Formação Profissional de Nível Médio (CEFAN), 33 alunos de nível médio da referida escola, e 21 auxiliares ou técnicos de enfermagem, funcionários da Santa Casa de Misericórdia, ambos da cidade de Passos, Estado de Minas Gerais, e cada um desses três grupos de sujeitos responderam aos questionários que seguem cada um deles contendo em sua parte inicial seus dados pessoais.

\section{Docentes do curso de Técnico e Auxiliar de enfermagem}

1 - Partindo do princípio de que o inter-relacionamento pessoal é base para as ações de enfermagem, como esse conteúdo é abordado na disciplina que você ministra? 2 - Como você avalia o preparo dos seus alunos para interagirem com o paciente?

3 - Como formador de Auxiliares e Técnicos de enfermagem, o que você sugere para uma assistência mais humanizada?

\section{Alunos do curso de Técnico e Auxiliar de enfermagem}

1 - Como você considera o relacionamento interpessoal no exercício de futuras funções?

2 - Durante o seu curso de formação, em quais disciplinas e como este conteúdo foi abordado?

3 - Como formando de Auxiliar Técnico de enfermagem, o que você sugere para uma assistência mais humanizada?

\section{Técnicos e Auxiliares de enfermagem}

1 - Você inclui o relacionamento Interpessoal nos procedimentos técnicos que desenvolve com pacientes?

2 - Como você considera o conteúdo sobre inter-relacionamento pessoal aprendido durante o seu curso de formação profissional? 
3 - Como Auxiliar ou Técnico de enfermagem, o que você sugere para uma assistência mais humanizada?

Os alunos que aceitaram participar do estudo, responderam o referido questionário em sala de aula, os professores responderam em local e hora combinada previamente, sendo que a pesquisadora esteve presente durante as respostas aos questionários para esclarecimentos a possíveis dúvidas.

Para aplicação dos questionários aos técnicos e auxiliares de enfermagem, foi treinada uma enfermeira do próprio hospital para este fim devido à facilidade de acesso aos diversos setores e turnos (matutino, vespertino e noturno), da escala de serviço, além do seu melhor entrosamento com o referido grupo.

Tratou-se de uma pesquisa social, pois refletiu posições frente à realidade, preocupações e interesses da enfermagem. Foi um estudo descritivoexploratório, com uma proposta de trabalho teórico-metodológica para abordagem qualitativa.

Os resultados do estudo mostraram a predominância do sexo feminino na enfermagem nas três categorias entrevistadas, sendo, desta forma, semelhante ao que ocorre nesta profissão, de maneira geral, e os sujeitos participantes do estudo estavam dentro de uma faixa etária que pode ser considerada como de grande produtividade, com grandes chances de busca de aperfeiçoamento profissional nas suas categorias.

Sobre a primeira pergunta feita aos sujeitos, constatou-se que 11 professores abordam o relacionamento interpessoal em suas disciplinas, 29 alunos consideram este conteúdo indispensável, fundamental, ou prioritário, e, dos 21 auxiliares ou técnicos de enfermagem, 20 responderam que incluem este tema nos 
procedimentos técnicos. Estes dados mostraram que os professores abordam o tema em suas disciplinas, os alunos relatam a sua importância e os auxiliares e técnicos relatam a utilização desta habilidade em seus procedimentos técnicos.

Com relação à segunda pergunta, 3 professores consideraram bom o preparo dos alunos para interagirem com o paciente, 3 acreditam que este preparo está em evolução, 2 responderam que este preparo é inadequado e 6 interpretaram a pergunta de forma incoerente com o estudo.

Dos alunos sujeitos, 20 citaram a psicologia como a disciplina que mais aprofundou o tema, mas citaram mais 13 outras disciplinas que abordaram o tema em seu curso. Dentre os funcionários entrevistados, 13 acreditam que o conteúdo aprendido sobre o tema foi ótimo, muito bom, ou bom; 5 responderam que este foi regular, vago, básico e rápido; e 3 responderam que não evidenciaram este conteúdo nos seus cursos. Isto confirma o comentário feito anteriormente sobre a fragmentação do conteúdo abordado nas diversas disciplinas, levando as dificuldades para identificar o real conteúdo ministrado, aprendido e aplicado.

Na terceira pergunta, que pede sugestões para uma assistência mais humanizada, observamos que as 3 categorias de sujeitos deram respostas mais claras e extensas. São coincidentes nas respostas destes, as sugestões de acompanhamento psicológico para a equipe de enfermagem, estudos, capacitação e educação continuada.

Essas sugestões pertencem de certa forma, ao conteúdo geral de relacionamento interpessoal e deveriam estar sendo aplicadas rotineiramente na prática profissional. No entanto, as formas fragmentadas do ensino deste tema em pouco contribuem para que exista uma prática sistematizada e efetiva deste 
procedimento, que é tido como base para as ações de enfermagem, embora não haja indicação precisa de como ele efetivamente ocorre.

Os alunos consideram de fundamental importância o relacionamento interpessoal no exercício de suas funções e ocorreu uma predominância na resposta de que "todas" as disciplinas abordaram o tema demonstrando que apesar de ser uma preocupação entre os professores, este conteúdo talvez não seja significativo ou pouco esclarecido, sendo justificado também o fato da segunda parte da questão de como o conteúdo é abordado ter sido respondida apenas por 3 alunos.

Sobre a percepção e atuação dos técnicos e auxiliares de enfermagem observou-se que não há referência nas respostas de que se aplica o relacionamento interpessoal em momento específico, separado de procedimentos técnicos. Questionou-se, pois que, se o relacionamento interpessoal estivesse sendo aplicado nas ações de enfermagem já se teria mostra, mesmo que pequena, da humanização da assistência, pois o cuidado humano não pode ser prescrito e não segue receitas. Ele é vivido, sentido e exercitado. Outro questionamento que achou-se necessário fazer foi sobre o fato de que se o ensino da habilidade de relacionamento interpessoal foi tido pela maioria dos profissionais como "bom”, porque não se conseguiu transformar a realidade da assistência de enfermagem mecanizada, predominante nos serviços de saúde, em uma assistência humanizada?

Apesar das respostas dos três grupos de sujeitos entrevistados demonstrarem a importância do relacionamento interpessoal, observou-se uma tendência em associar o tema com algum procedimento ou técnica executada pela enfermagem. 
Constatou-se que os professores buscaram abordar o tema, a maioria dos alunos confirmou que aprenderam o conteúdo, e, também, a maioria dos profissionais de nível médio afirmou que o tema visto em seus cursos foram bons. As falas dos sujeitos em suas respostas levaram a acreditar que o discurso é diferente da prática, ou que o cuidado ideal é diferente da realidade vivida. Será que este conteúdo não foi abordado e assimilado superficialmente, tornando-se pouco significante para os sujeitos? Ou será que o tema foi apenas falado, mas não vivido pelos profissionais de saúde e pelos educadores? A formação instrumental ainda está sobressaindo sobre a formação expressiva? São questionamentos que não se pode responder com certeza.

Entende-se que a produtividade de um grupo assim como sua eficiência estão estreitamente relacionadas com a competência e com as relações interpessoais de seus membros. Sendo assim, o enfermeiro precisa visualizar cada membro de sua equipe como um ser único, com capacidades e dificuldades, para atingir a eficiência. Acredita-se que o conhecimento das necessidades interpessoais dos membros de um grupo é imprescindível para o bom entrosamento e a produtividade do seu trabalho (SAWADA et al. 2000).

Na formação profissional em enfermagem, pode-se ver que o conteúdo relativo ao relacionamento interpessoal é pouco abordado, e este tem como alvo de abordagem o paciente, e raramente tal conteúdo é apresentado e discutido como recurso de qualificação do relacionamento nos integrantes da equipe de enfermagem e, consequentemente, qualificação do trabalho (PIROLO, 1999).

Assim, hoje, iniciando o $3^{0}$ milênio, onde busca-se resgatar valores até então adormecidos, relacionados à visão de integralidade da pessoa humana, a 
enfermagem deve buscar uma séria reflexão de sua prática profissional na formação dos recursos humanos necessários neste processo do cuidar, pois a experiência prática mostra a deficiência com que a equipe de enfermagem se relaciona com os pacientes.

Desta forma, estimulado pelos resultados do estudo ora descrito, sentiuse a necessidade de continuar estudando este tema, investigando a percepção do paciente sobre o Relacionamento Interpessoal como técnica voltada à recuperação da sua saúde. 


\section{MODELOS BÁSICOS DE ASSISTÊNCIA EM SAÚDE MENTAL}

Para conhecer melhor alguns aspectos das relações interpessoais faz-se necessário rever resumidamente fundamentos teóricos de alguns modelos de assistência, dentre os quais o modelo médico, o modelo comportamental, o modelo psicodinâmico, o modelo preventivista, o modelo social, o modelo existencial, o modelo cognitivo, o modelo holístico e o modelo humanista, pois sabe-se que todos estes modelos contribuíram para a compreensão da saúde e da assistência ao paciente psiquiátrico, influenciando nas instituições, na sociedade, e na sua assistência. A revisão destes fundamentos teóricos foi baseada em estudos de Kaplan (1997), Luque \& Villagran (2000), Stuart \& Laraia (2001), Furegato (1999), Giovani (2005), Guimarães (2005) e Teixeira (2005). 


\subsection{Modelo médico}

É o mais antigo dos modelos e exerce grande influência na assistência pois suas bases estão nas causas naturalistas, ou seja, nas causas físicas para explicar as doenças mentais, classificando-as e definindo diagnóstico e tratamento.

As rupturas de comportamento resultam de uma doença biológica, portanto, determina-se deste modo que o observado no corpo, é também observado na mente, e qualquer pessoa que apresenta algum distúrbio é denominada doente. Assim, a doença pode ser diagnosticada, classificada e o tratamento é baseado na história do doente, através de drogas, químicas, hormônios, vitaminas, sedativos, psicocirurgias, e eletroconvulsoterapia. O terapeuta utiliza apenas o diagnóstico da doença e prescreve a conduta terapêutica.

A prática de enfermagem vive uma relação de dominação por parte do poder médico, aparecendo neste modelo como submissa, e sua atuação deve ser universalista, específica, afetivamente neutra e de orientação coletiva. Diante do grande avanço tecnológico, a enfermagem se especializa e se torna cada vez mais tecnicista, mostrando, assim, uma atitude profissional de distanciamento e envolvimentos nas relações humanas.

A crítica que se faz a este modelo é que ele tem uma visão reducionista e biologicista considerando o transtorno mental como um desequilíbrio biológico, não descrevendo assim uma visão completa do mesmo e as explicações para as causas desse transtorno não são adequadas para a conduta psicopatológica. 


\subsection{Modelo comportamental}

É baseado nas teorias de aprendizagem, na psicologia e fisiologia. Seus principais representantes são Pavlov, Skinner e Staats, sendo estes responsáveis por vários estudos de comportamentos. Este modelo determina que o comportamento é a expressão de um organismo, podendo ser observado, descrito, recordado e reelaborado. Determina que o comportamento é aprendido e pode ser também desaprendido. O terapeuta baseia o tratamento no conhecimento e aplicação dos princípios da aprendizagem, além de alguns métodos auxiliares utilizados como: relaxamento, hipnose e drogas. Encara a terapia como um processo educativo.

O terapeuta ensina o paciente sobre a conduta comportamental, ajuda a desenvolver a hierarquia de comportamento e reforça os comportamentos desejados. Pouca ênfase é dada a essa linha comportamental na enfermagem, os que atuam neste modelo devem ter conhecimento do tratamento, paciência e conduta de ação contínua.

Este modelo pode receber críticas por se fundamentar em teorias de aprendizagem, que são questionáveis, ignora os aspectos da psíquica e que a experiência humana se reduz a um simples registro de dados observados.

\subsection{Modelo psicodinâmico}

Tem como principal representante Freud, que partindo de conceitos de fisiologia, neurologia e neuropatologia, aplicou-os na psicanálise. Responsável pela criação da psicanálise, solidificou a idéia de que os traumas causadores das 
perturbações provocadas pelo libido enquanto energia vital, impulsos reprimidos na infância, e a não solução dos conflitos seria responsável pelas neuroses. Pesquisou os sistemas da psique, consciente, inconsciente e pré-consciente, e as estruturas id, ego e superego, a energia, os mecanismos de defesa e os instintos de vida e de morte.

No modelo psicanalítico o tratamento é focalizado no relacionamento terapeuta-paciente. É de longa duração e visa descobrir as raízes dos conflitos através dos relatos do paciente que verbaliza todos os pensamentos e sonhos e leva em consideração as interpretações do terapeuta, que permanece distante para estimular o desenvolvimento da transferência e interpreta os pensamentos e sonhos do paciente em relação aos conflitos, à transferência e à resistência. As técnicas mais usadas são a livre-associação, interpretações dos sonhos e o insight na busca do conhecimento, na superação das resistências e na alteração do ego.

São raras as participações da enfermagem nas atividades psicanalíticas, e o que se encontra mais comumente, são atuações como co-terapeutas, conselheiros, visitadores ou ego-auxiliares, mesmo assim, é essencial o conhecimento destes fundamentos psicanalíticos para o oferecimento de uma boa assistência.

Críticas a este modelo podem ser feitas no sentido de questionar a psicanálise como teoria e ciência, devido à impossibilidade de se verificar empiricamente suas propostas, além de ser considerada uma terapia de pouca eficácia terapêutica. 


\subsection{Modelo preventivista}

Seus maiores representantes são Level e Clark na medicina preventiva e Caplan na psiquiatria. Inclui equipes multiprofissionais, participação de comunidades e governo. Utilizam-se conceitos de psiquiatria, de comunidade, de psiquiatria social e teoria de sistemas. O enfoque deste modelo é a saúde, ou seja, a prevenção de doenças, e o fundamento de que toda pessoa em algum momento de sua vida passa por dificuldades esperadas ou acidentais. As ações deste modelo estão centradas em três níveis de prevenção: prevenção primária que visa manter e promover a saúde; prevenção secundária, que visa diminuir o tempo de doença, eliminá-la o mais rápido possível restabelecendo a saúde, evitando seqüelas e invalidez; e a prevenção terciária, que busca manter a integridade do doente como pessoa, através da reabilitação, utilizando suas capacidades e potencialidades mesmo quando a doença deixou seqüelas e invalidez.

O tratamento é baseado no conhecimento e aplicação de princípios da medicina social, preventiva e teoria dos sistemas. Neste modelo, a enfermagem não tem ainda seu papel totalmente definido devido às amplas atividades que podem ocorrer desde a prevenção, à cura e à reabilitação do paciente psiquiátrico, mas em qualquer um destes a ação da enfermagem é fundamental para ajudar o indivíduo.

Este modelo necessita de grande aplicação de recursos financeiros por parte do governo, e, de um modo geral, nesse meio, apenas parte dos planos elaborados tem sido aplicada, já que estas ações nem sempre geram lucros para a sociedade capitalista. 


\subsection{Modelo social}

Os principais representantes deste modelo são Szasz e Caplan onde se acredita que fatores sociais e ambientais criam o estresse, que provoca ansiedade, resultando na formação do sintoma. O paciente recebe ajuda para lidar com o sistema social, e pode-se utilizar a intervenção de crise, a manipulação ambiental e estimular o apoio dos amigos. O paciente apresenta ativamente o problema ao terapeuta e trabalha com este no sentido da solução. São utilizados recursos comunitários e o terapeuta explora o sistema social do paciente, ajudando-o a usar os recursos disponíveis ou criar novos recursos.

Importante salientar, que este modelo não tem seus fundamentos baseados em estudos e métodos de conhecimento científico, além de reduzir toda conduta humana no âmbito social.

\subsection{Modelo existencial}

A vida tem sentido quando a pessoa aceita-se plenamente. O desvio de comportamento ocorre quando o indivíduo é tolhido no seu esforço para encontrar-se e aceitar-se. No processo terapêutico a pessoa é estimulada a ser autêntica no relacionamento. A terapia é freqüentemente conduzida em grupos. O paciente assume a responsabilidade pelos comportamentos e participa em experiências para aprender sobre seu eu real. O terapeuta ajuda o paciente a reconhecer seu próprio valor. O terapeuta esclarece as realidades da situação e introduz o paciente aos 
sentimentos genuínos e à consciência expandida. Os principais representantes deste modelo são Peris, Glasser, Ellis, Rogers e Frankl.

Críticas a este modelo podem ser feitas no sentido de que há dificuldades em se construir uma linguagem científica e com uma terminologia clara, ou seja pode prevalecer a utilização de metáforas nas descrições dos comportamentos (fenômenos) observados (CASTILLA DEL PINO, 1991).

\subsection{Modelo cognitivo}

A perturbação psíquica está baseada em uma disfunção do pensamento. São objetos de estudo: a atenção, a percepção, a memória, as intenções, as atitudes, os sentimentos e tudo que faz parte da estrutura do conhecimento e participam de sua aquisição e transformação. Em saúde mental se define em três fatores: a habilidade de se adaptar as demandas, a capacidade para equilibrar a adaptação e atualização e as atitudes de autonomia funcional. A descrição das condutas anormais se revela nas respostas das distorções cognitivas. O tratamento é a aplicação da técnica de terapia cognitiva, mas é empregado também como método de estudo do funcionamento dos processos cognitivos (atenção, percepção e memória), seus conteúdos (atribuições e categorias) e consciência. Seus principais representantes são Beck e Ellis.

O modelo cognitivo pode receber críticas pela sua postura filosófica que está implícita na perspectiva funcionalista, com manejo de símbolos e aplicação de regras, com o paradigma cognitivo superando os mecanismos afetivos. 


\subsection{Modelo holístico}

Representa um novo paradigma científico e filosófico no qual o homem é visto como "inteiro" ou "todo" e integram o conjunto entre a mente, o corpo e o espírito. Chamado modelo biopsicosocial este engloba o nível biológico, psicológico e o social. Este modelo se baseia na inter-relação dos fenômenos no qual o humano tem ligação com todo o universo. As doenças são vistas como um desequilíbrio em um ou mais componentes do indivíduo, exteriorizando os distúrbios internos na esfera física, psíquica e ou social.

A crítica que se faz a este modelo é quanto a sua intenção de descobrir, mais do que de explicar, a conduta humana anormal, sendo de pouco valor para a investigação dos transtornos mentais.

\subsection{Modelo humanista ou interpessoal}

Privilegia a pessoa como centro da atenção de saúde e vem se desenvolvendo desde que existe a preocupação do corpo-mente do homem, valorizando-o pelo que ele é. Visam seu relacionamento com o mundo, as relações interpessoais na família, no trabalho e no mundo. Supõe que uma pessoa é mais ativa e produtiva na medida em que conhece a si mesma, seus sentimentos e atitudes.

Apresenta várias formas de tratamento, cujas terapias visam o autoconhecimento, valoriza conceitos como a aceitação e a empatia, fundamentais tanto ao paciente quanto ao terapeuta, para que ambos se transformem em uma relação. 
Este modelo promove transformações na organização, administração e prestação da assistência, e exige da enfermagem uma nova postura, ou seja, comportamentos humanistas, que é baseado na relação de ajuda e na interação enfermeiro-paciente, onde o paciente precisa de segurança e satisfação que decorrem de relacionamentos interpessoais positivos. A enfermagem utiliza sua pessoa como instrumento para ajudar o paciente a encontrar soluções próprias para suas necessidades. A atuação da enfermagem é de compreensão, colocando o paciente no centro da assistência, podendo ouvi-lo, buscando ajudá-lo para suas necessidades (PEPLAU, 1952; TRAVELBEE, 1982; FUREGATO, 1999).

Espera-se que toda a atuação da enfermagem deva ocorrer de maneira compreensiva, privilegiando o paciente como centro da assistência, já que este profissional surgiu da necessidade de se ter pessoas cuidadoras dos doentes. Neste modelo, o terapeuta desenvolve um relacionamento estreito com o paciente; utiliza a empatia para perceber os sentimentos do paciente e utiliza o relacionamento como uma experiência interpessoal corretiva.

Silva et al. (2001) investigando enfermeiros que associaram o cuidado de enfermagem à realização de procedimentos, onde esses profissionais demonstraram entender o cuidado como administração de medicamentos, técnicas de higiene e curativo, dentre outros, verificaram que apesar da grande prevalência dos procedimentos técnicos, os enfermeiros também salientaram que seu cuidado profissional é permeado pela relação interpessoal entre enfermeiro e paciente, citando carinho, paciência e educação como manifestações de cuidado.

O presente estudo tem uma forte relação com este modelo de assistência e buscou neste a base para o seu desenvolvimento, análise de dados e conclusões. 
Contudo, como nos outros modelos, alguns aspectos no sentido crítico devem ser destacados. Conhecer-se a si é um pré-requisito importante para o desenvolvimento de um boa relação interpessoal, e isso nem sempre é levado em consideração nos serviços de assistência em saúde, principalmente em se tratando de profissionais de nível médio enfermagem. As supervisões, associadas à educação continuada em serviço, de certa forma daria aos referidos profissionais uma condição melhor de abordagem e o estabelecimento, manutenção e término de um relacionamento interpessoal. Ocorre que, os serviços de assistência nos meios hospitalares brasileiros, ainda não estão atentos para isso, e, desta forma, as relações, quando são estabelecidas, deixam a desejar no sentido de se saber se estão sendo realizadas de forma adequada e perde-se grandes oportunidades de ajustes e avanços na busca da utilização deste relacionamento como um instrumento extremamente terapêutico. Enfim, nesse sentido, há um caminho longo a percorrer até que os serviços adotem medidas que garantam a inclusão de técnicas como esta em suas atividades terapêuticas, garantindo também os treinamentos para isso, e, as escolas, principalmente as de ensino no nível médio de enfermagem, com base nas de nível superior, também passem a valorizar de vez esses aspectos.

Entende-se que os modelos de assistência em saúde mental contribuem de maneira ímpar para a construção da enfermagem como ciência e também na aplicação de seus fundamentos no cuidado direto ao paciente. Há predominância do modelo médico, pois o diagnóstico é privilegiado na maioria das instituições de saúde e também nas de ensino, e a assistência, de modo geral, tem sua base neste diagnóstico, privilegiando a formação instrumental, com aplicação de técnicas e procedimentos. O modelo preventivista tem destaque nas atuações do Programa de 
Saúde da Família. Os conceitos do modelo psicodinâmico, como consciente, inconsciente, história familiar constituem-se em bases para programar ações de enfermagem. O modelo interpessoal permite planejar a assistência centrada nas necessidades do paciente, onde a enfermagem pode realizar seu papel terapêutico.

Atualmente o modelo cognitivo-comportamental tem sido utilizado na assistência de diversos quadros psicopatológicos, principalmente os provenientes da ansiedade. Os simpatizantes do modelo holístico têm aumentado, principalmente após a ampliação dos serviços abertos de assistência psiquiátrica e o aparecimento de novas modalidades terapêuticas, buscando a integração corpo, mente e espírito. Enfim, a assistência de enfermagem e particularmente a enfermagem psiquiátrica busca apoio em todos os modelos, pois procura se adequar a evolução da psiquiatria, que hoje pede uma visão ampliada de seus profissionais, em todas as áreas de atuação, objetivando uma assistência integrada.

A enfermagem precisa assistir os pacientes com ética e dignidade, utilizando conhecimentos científicos e técnicos, sendo criativa, procurando humanizar este atendimento, com menores riscos. O cuidado exige observação contínua, atendimento com calor humano, permitindo que todos os aspectos relacionados ao cliente façam parte do cuidado, para manter uma adequada e capacitada relação profissional, o que consiste se constituem um grande desafio. 


\section{OBJETIVOS}

Investigar junto a pacientes de clínica médica, cirúrgica e psiquiátrica sua compreensão sobre Relacionamento Interpessoal e qual a importância desta habilidade; observar como ocorre o Relacionamento Interpessoal entre auxiliares e técnicos de enfermagem com os pacientes das referidas clínicas, o motivo que os levou a este relacionamento e a freqüência desta interação; comparar os dados obtidos da percepção do paciente com a observação direta dos técnicos e auxiliares de enfermagem. 


\section{TRAJETÓRIA METODOLÓGICA}

\subsection{Características do estudo}

Trata-se de uma pesquisa social, pois reflete posições frente à realidade, preocupações e interesses de classes e de grupos determinados, a enfermagem. É a continuação de um estudo realizado no Mestrado sobre o Relacionamento Interpessoal, sendo este, um estudo descritivo-exploratório, com uma proposta de trabalho teórico-metodológica para abordagem qualitativa. A abordagem metodológica qualitativa justifica-se por não ser possível operacionalizar em números e variáveis um trabalho que envolve relações humanas e sociais no campo da saúde, buscando explicar os meandros das relações sociais consideradas essência e a atividade humana que pode ser apreendida através do cotidiano, da vivência e da explicação do senso comum.

Para Minayo (2000) “qualquer investigação social implica considerar sujeito de estudo gente, em determinada condição social, pertencente a determinado grupo social ou classe com suas crenças, valores e significados”. Ainda, segundo a autora, existe hoje, uma valorização dos significados que fortificam a introspecção 
do homem, a observação de si mesmo e se ressaltam questões antes passadas despercebidas.

Sabe-se que a saúde é uma preocupação comum a todos os cidadãos, independente de sua classe social e cultura, sendo esta influenciada pelos aspectos físicos, psicológicos, ambientais, sociais e econômicos, e, desta forma firma-se um comprometimento em tentar atingir os objetivos já propostos sobre o tema e expressar a realidade obtida através deste estudo.

\subsection{Contexto do estudo}

O estudo foi desenvolvido na cidade de Passos, Estado de Minas Gerais, que possui 98570 habitantes, com três (3) hospitais (Hospital São José, Hospital Otto Krakauer e Santa Casa de Misericórdia), um Pronto Socorro Municipal, oito (8) Unidades Básicas de Saúde e 17 equipes do Programa de Saúde da Família.

A obtenção da coleta dos dados foi centrada em duas instituições:

1- Santa Casa de Misericórdia de Passos (SCMP): trata-se de um hospital geral, regional, filantrópico, com 213 leitos que atende pacientes de convênios, SUS e particulares. Tem uma média de 1500 internações/mês, divididas nas especialidades médico-cirúrgicas, obstetrícia e neonatologia, pediatria e terapia intensiva. As clínicas médicas e cirúrgicas, escolhidas para este estudo, consistem de enfermarias com três (3) leitos e atende pacientes do Sistema Único de Saúde (SUS). O Departamento de Enfermagem desta instituição é composto por 223 funcionários, enfermeiros, técnicos e auxiliares de enfermagem, que compõem a equipe de enfermagem. A jornada de trabalho destes é de oito (8) horas diárias, sendo que o 
turno da manhã inicia as 6:45 horas e termina 15:15 horas, da tarde inicia 14:45 horas e termina 23:15 horas e noturno inicia 22:45 horas e termina 7:15 horas.

2- Hospital Otto Krakauer: trata-se de um hospital psiquiátrico, com 120 leitos, que atende pacientes conveniados ao SUS, tendo como taxas de ocupação a seguinte distribuição: cinqüenta por cento dos pacientes são portadores de psicose e cinqüenta são dependentes químicos (alcoolistas). A jornada de trabalho da equipe de enfermagem é de seis horas no turno matutino inicia 7:00 horas e termina 13:00 horas, vespertino inicia 13:00 horas e termina 19:00 horas e noturno que inicia 19:00 horas e termina 7:00 horas.

A escolha destas instituições ocorreu pelo fato dos dois hospitais atenderem especialidades médicas distintas, possibilitando assim, a escolha de pacientes de clínicas diferentes para este estudo e também por serem locais utilizados para atividades clínico-práticas da pesquisadora e de alunos tanto de curso de graduação em enfermagem, quanto de cursos de nível médio desta profissão.

\subsection{Participantes do estudo}

Fizeram parte deste estudo, pacientes conveniados ao SUS, internados nas clínicas médica e cirúrgica da Santa Casa de Misericórdia de Passos e pacientes psiquiátricos do Hospital Otto Krakauer, também do SUS, que estiveram internados durante o período estipulado para entrevista e observação. Foram utilizados dez (10) pacientes para entrevista nas Clínicas Médica e Cirúrgica da Santa Casa e cinco (5) no Hospital psiquiátrico. Para a observação, foram utilizados quarenta e oito (48) pacientes da Santa Casa, sendo vinte e quatro (24) da Clínica Médica e vinte e quatro (24) da Clínica Cirúrgica, sendo que foram observados os pacientes em cada 
enfermaria, nos seus respectivos leitos. Do Hospital Psiquiátrico foram observados vinte e quatro (24) pacientes, para se manter o mesmo número de pacientes observados em cada especialidade.

Fizeram parte, também, profissionais de nível médio de enfermagem, auxiliares e técnicos de enfermagem, presentes nos plantões escolhidos para observação, sendo oito (8) na clínica médica, sete (7) na clínica cirúrgica e cinco (5) na clínica psiquiátrica. Os enfermeiros foram excluídos do estudo por não estarem presentes continuamente nas clínicas médica, cirúrgica e psiquiátrica, devido sua função de supervisão em mais de uma clínica.

\subsection{Procedimentos éticos}

Os sujeitos do estudo foram convidados de forma verbal a responderem a uma entrevista (Apêndice 1) que foi também gravada. Nesta oportunidade, foi esclarecido a eles os motivos e objetivos da pesquisa, a importância de sua contribuição, e feito uma justificativa de sua escolha como entrevistado. Foi garantido também o seu anonimato e o sigilo de suas respostas (Apêndices 2 e 3).

Foi solicitado também à direção de cada instituição a autorização para pesquisar nas unidades, explicando seus objetivos, as entrevistas e as observações que foram realizadas. Em seguida foram realizadas visitas nas unidades onde ocorreu a pesquisa para explicar às chefias de enfermagem e suas equipes a intenção desta e deixar claro que não se buscava avaliar ou julgar suas atividades, mas que se almejava a coleta de alguns dados específicos. 
A coleta de dados ocorreu do dia dezessete de janeiro à dezoito de fevereiro de dois mil e cinco após o projeto ter sido aprovado pelo Comitê de Ética da Escola de Enfermagem de Ribeirão Preto da Universidade de São Paulo (Anexo $1)$.

\subsection{Procedimentos para a coleta dos dados}

Para a coleta de dados do presente estudo, foram realizadas entrevistas (Etapa A) pela pesquisadora com dez (10) pacientes da Santa Casa e cinco (5) pacientes do Hospital Otto Krakauer. Com esta finalidade foi utilizado um roteiro de entrevista semi-estruturada com questões abertas e específicas, para ser aplicado ao grupo de pacientes selecionados (Apêndice 1) e um minigravador. Salienta-se que antes de ser aplicado nos sujeitos do estudo, este instrumento foi analisado previamente, por dois juizes experientes em pesquisa que o consideraram adequado e foi realizado um pré-teste com pacientes que não fizeram parte da amostra final da pesquisa.

Para Minayo (2000) a entrevista semi-estruturada visa apreender o ponto de vista dos atores sociais, orienta uma "conversa com finalidade”, facilita, amplia e aprofunda a comunicação. Ainda conforme esta autora este tipo de entrevista combinando perguntas estruturadas e abertas oferece ao entrevistado a possibilidade de discorrer sobre o tema.

As entrevistas foram realizadas nas enfermarias das clínicas médica e cirúrgica no período matutino, de dez às onze horas e trinta minutos, conforme sugestão das enfermeiras chefe de unidade, e no hospital psiquiátrico às treze horas, 
horário também sugerido pela enfermeira coordenadora , sendo este o horário que não causaria transtorno na rotina das unidades.

De acordo com Triviños (1994, p.146), a entrevista semi-estruturada é aquela:

“...que parte de certos questionamentos básicos, apoiados em teorias e hipóteses que interessam à pesquisa e que em seguida oferecem amplo campo de interrogativas, fruto de novas hipóteses que vão surgindo à medida que se recebem respostas do informante."

Foram utilizados também observações e registros contínuos das atividades desenvolvidas pelos auxiliares e técnicos de enfermagem com os pacientes selecionados, etapa B da coleta de dados. Para Furegato (1999), a necessidade de captar o que acontece na relação enfermeiro-paciente, através da “observação direta”, busca captar o sentido da ação humana através da constatação de fatos e se faz na tentativa de diminuir a distância entre a teoria e a prática, pela aquisição de conhecimentos, refletindo-se sobre a prática profissional, estimulando e promovendo transformações.

As observações foram realizadas pela pesquisadora e por duas alunas do curso de técnico em enfermagem que foram previamente treinadas para executar tal função, denominadas a partir daqui de monitoras. Para esta finalidade utilizou-se uma definição operacional de "Relacionamento Interpessoal” feita com base na descrição de Furegato (1999, p.55): habilidade a ser desenvolvida ao se executar qualquer procedimento de enfermagem, ou seja, em qualquer aproximação entre o integrante da equipe de enfermagem e o paciente na enfermaria ou em outro lugar do hospital (corredor, pátio, etc), com o propósito de prover alguma necessidade de 
conforto, higiene, medicação e outros. Outra forma é quando ocorre o relacionamento terapêutico, sendo que o enfermeiro coloca-se a disposição do paciente com o objetivo de ajudá-lo, caracterizando uma relação de ajuda, com início, desenvolvimento e desfecho, como por exemplo, em uma situação de crise ou de sofrimento.

Essas monitoras, utilizando a definição operacional do "Relacionamento Interpessoal”, as observaram durante plantões da equipe de enfermagem, por duas (2) horas em cada plantão, a maneira como ocorria o relacionamento interpessoal entre os técnicos e auxiliares de enfermagem e os pacientes. Registraram continuamente todos os comportamentos que ocorreram na enfermaria selecionada com o paciente e com os técnicos e auxiliares de enfermagem, e ainda, o motivo desse relacionamento, procurando interferir o mínimo possível na rotina do serviço. Cada monitora observou apenas uma enfermaria contendo no máximo três (3) pacientes por dia na Santa Casa. No Hospital Psiquiátrico, cada monitora acompanhou e observou apenas um paciente por vez, seguindo-o onde ele ia. A duração das observações também foi de duas horas. As monitoras registraram suas observações em um caderno de campo.

O horário para se fazer as observações foi escolhido de acordo com as rotinas dos hospitais, ou seja, elas foram realizadas em um período em que a equipe de enfermagem tinha possibilidades de realizar a habilidade de relacionamento interpessoal. Evitou-se o início da manhã, horário de almoço, de visitas e de passagem de plantão, devido a equipe estar envolvida com diversas atividades nestes momentos. Dessa forma, o horário ideal para as observações nos dois hospitais, esteve entre 15:00 horas e 17:00 horas, sendo assim este o período escolhido. Importante destacar que as alunas de enfermagem, observadoras, foram convidadas 
para tal atividade por serem alunas que tiveram destaque no curso técnico em enfermagem. As chefias de enfermagem das clínicas pesquisadas foram previamente contatadas por telefone no sentido de informar a realização da atividade de coleta de dados do presente estudo. Diariamente para as finalidades deste estudo foi passada visita em todas as enfermarias, masculina e feminina, e a sua escolha para observação de seus pacientes foi aleatória.

Nas duas clínicas, médica e cirúrgica, o plantão da enfermagem é passado na porta de cada enfermaria, pelos técnicos e auxiliares de enfermagem escalados para o plantão. As enfermeiras chefes das referidas clínicas passam o plantão para a enfermeira supervisora no posto de enfermagem. Segundo a escala na clínica médica e cirúrgica o plantão da tarde é composto por sete ou oito profissionais de nível médio de enfermagem, escalados para o período da tarde. Cada técnico ou auxiliar de enfermagem fica responsável por duas enfermarias, aplicando cuidado integral, ou seja, responsável por toda assistência desses pacientes.

As observações iniciaram-se pela clínica médica. O número de pacientes masculinos e femininos, observados em cada enfermaria desta clínica foi de três (3) que pertenciam às enfermarias denominadas M1, M2, M3, M4, M5, M6, M7 e M8, onde observou-se vinte e quatro pacientes. Em seguida, passou-se para a clínica cirúrgica, nas enfermarias denominadas C1, C2, C3, C4, C5, C6, C7, C8, e C9, cujo número de pacientes observados masculinos e femininos, variou de um à três conforme disponibilidade daquele momento, totalizando vinte e quatro observações. Estes pacientes foram identificados com números de 1 a 48.

No hospital psiquiátrico, faz parte da escala de enfermagem uma enfermeira supervisora para atender tanto a clínica feminina quanto a masculina e 
estão escalados cinco (5) auxiliares de enfermagem em cada clínica. As observações realizadas nos vinte e quatro pacientes psiquiátricos, masculinos e femininos, denominados de 49 a 72, ocorreram no pátio, na sala de televisão, nas enfermarias e até mesmo nos consultórios médicos, conforme a movimentação de cada paciente.

Em todos os pacientes observados preocupou-nos anotar a freqüência com que os auxiliares e técnicos de enfermagem entravam em contato com estes pacientes e descreveu-se o motivo pelo qual este ocorria, conforme detalhado na apresentação dos resultados.

\subsection{Procedimento de análise de dados}

Gil (1994) afirma que a análise dos dados tem a finalidade de organizar e resumir os dados obtidos durante a investigação possibilitando assim, o fornecimento de respostas ao problema proposto. “A análise é desenvolvida através da discussão que os temas e os dados suscitam....e da relação entre as hipóteses de trabalho e sua confirmação ou não na pesquisa” (VICTORA, KNAUTH \& HASSEN, 2000).

Para interpretação dos dados coletados utilizou-se como referencial teórico a análise de conteúdo que se define por uma técnica que busca descrever o conteúdo das mensagens, de maneira objetiva, sistemática, com finalidade de interpretá-los e “alcançar uma vigilância crítica frente à comunicação de documentos, textos literários, biografias, entrevistas e observações” (MINAYO, 2000). A autora propõe alguns passos para a análise dos dados coletados:

$1^{\text {o }}$ - ordenação dos dados, incluiu-se nesta etapa a transcrição das fitas gravadas seguida de uma cuidadosa leitura do material coletado nas observações e nas entrevistas. Durante a análise dos dados coletados buscou-se não só enxergar os 
conteúdos explícitos nas falas e observações, mas também os subjetivos, contidos nas entrelinhas.

$2^{\circ}$ - classificação dos dados, constituída de leitura repetida dos textos, o que permite apreender as idéias centrais do tema e posteriormente reagrupá-las em categorias. As respostas dos sujeitos pesquisados foram separadas e agrupadas com base na aproximação das idéias e expressões contidas no seu conteúdo. Trechos descritivos (do próprio sujeito) ilustraram a apresentação dos resultados e a discussão dos mesmos. Foram também computados a freqüência e os motivos das interações ocorridas entre as equipes e os pacientes.

$3^{0}$ - análise final, inclui o objeto, o sujeito do conhecimento e as interrogações daquele momento, sugerindo que ao final do trabalho possam ser indicadas mudanças, avaliação de programas, transformação de relações e outros. 


\section{RESULTADOS E DISCUSSÃO}

Após a análise do conteúdo dos dados coletados, optou-se por apresentar os resultados em quadros que permitem uma melhor visualização, classificando as respostas em categorias, com agrupamento por unidade de registro (palavras) considerando a freqüência com as quais elas aparecem no discurso dos entrevistados. Em seguida, partiu-se para os discursos com base na literatura pertinente.

Os quadros numerados de 1 a 14 referem-se aos conteúdos das respostas dos sujeitos, identificados como P1 até P15, nas entrevistas (Apêndice 1). Os quadros apresentados de 15 a 17 referem-se às sínteses das observações realizadas. 
Quadro 1 Visão dos pacientes de como são tratados pelas pessoas que trabalham no hospital.

\begin{tabular}{|c|l|}
\hline PACIENTE & \multicolumn{1}{|c|}{ COMO É TRATADO } \\
\hline P1 & Bem. \\
\hline P2 & Até agora muito bem \\
\hline P3 & Muito bem tratado, não tenho reclamação \\
\hline P4 & Bem, sempre bem \\
\hline P5 & $\ldots$ tudo bem, eles são bons demais, ... \\
\hline P6 & Eu sou tratado muito bem aqui. \\
\hline P7 & Bem, graças a Deus. \\
\hline P8 & Graças a Deus eu sou bem tratado por todos, \\
\hline P9 & ... \\
\hline P10 & Sou muito bem tratada \\
\hline P11 & Super bem. \\
\hline P12 & Eles me tratam bem. \\
\hline P13 & Bem, não tem nada a reclamar de ninguém. \\
\hline P14 & Sou bem tratado, graças a Deus. \\
\hline P15 & Tudo bem, é ótimo \\
\hline
\end{tabular}

Nota-se que dos quinze pacientes entrevistados todos relataram serem bem tratados. Apesar desta fala geral, alguns pacientes referiram medo de brutalidade, falta de educação e de atenção, principalmente no hospital psiquiátrico, conforme os trechos: 
"eu respondo na hora certa, quando tem brutalidade comigo, porque tem pessoa que não tem educação”. (P13)

"Tratam bem. Elas não dão atenção. Até eu fui conversar com um enfermeiro e elas mandaram eu sair”. (P11)

Considerando os conteúdos da fala geral dos pacientes e os outros dizeres complementares que apareceram também nas respostas durante as entrevistas, foi feito um reagrupamento que resultou na categoria 1 apresentada no quadro a seguir:

Quadro 2 Categoria 1- Percepção dos pacientes de como são tratados.

\begin{tabular}{|c|c|}
\hline $\begin{array}{l}\text { PERCEPÇÃO POSITIVA } \\
(15)\end{array}$ & $\begin{array}{l}\text { “.. bem”/ “ ....não tenho reclamação”/ “ } \\
\text {...eles são bons demais"/ “... Graças a } \\
\text { Deus”/ “...nada a reclamar de ninguém”/ “ } \\
\text {...é ótimo"/ “ ...o que podem fazer, } \\
\text { fazem.” }\end{array}$ \\
\hline $\begin{array}{l}\text { PERCEPÇÃO NEGATIVA } \\
(2)\end{array}$ & $\begin{array}{l}\text { “... brutalidade”....não têm educação...”/ } \\
\text { “...não dão atenção... mandaram, eu sair." }\end{array}$ \\
\hline
\end{tabular}

Durante as entrevistas foi possível perceber um certo constrangimento dos pacientes, dificuldade em fazer queixas do serviço, como se os mesmos não tivessem direito de fazer pedidos e até mesmo de exigir uma assistência de saúde adequada, independente da classe econômica que pertencem, conforme as falas:

“... como aqui é parte dos pobres, do SUS, tá a mesma coisa do particular”. (P5)

“Eu acho que o quê vocês podem fazer vocês fazem, não precisa nem pedir”. (P8) 
Entende-se que quaisquer que sejam as condições em que se desenvolve a prestação de cuidados, os comportamentos profissionais devem ocorrer com o propósito central de promover, fomentar e manter, nos utilizadores dos serviços, os direitos inerentes às pessoas (CATARINO et al., 1996).

Outra constatação é a de que ainda nos dias atuais o cuidado é visto como um ato de caridade, ligado á espiritualidade das pessoas, freqüentemente referido com sentimentos de gratidão, expressando emoção, como o paciente três (3), que no momento em que foi perguntado como é tratado, este começou a chorar e disse que não precisava melhorar em nada o tratamento, "só agradecimento".

“Graças a Deus eu sou bem tratado por todos, graças a Deus” (P8).

Quadro 3 Respostas dos pacientes sobre os conteúdos das conversas com os técnicos e auxiliares de enfermagem e as situações em que elas ocorrem .

\begin{tabular}{|c|c|c|c|c|}
\hline Pacientes & Contato & $\begin{array}{c}\text { Tipo de } \\
\text { conversa }\end{array}$ & $\begin{array}{c}\text { Situações da } \\
\text { conversa }\end{array}$ & $\begin{array}{c}\text { Conteúdo da } \\
\text { conversa }\end{array}$ \\
\hline P1 & Não & Não & Não & Não \\
\hline P2 & Entra e & Breve e & Medicação e & Brincadeiras \\
& conversa & freqüente & visita & Técnica \\
\hline P3 & Conversam & Perguntas & Tratamento \\
\hline P4 & Conversam & Breve & Visita & Tratamento \\
\hline P5 & Conversam & Agradável & $\begin{array}{c}\text { Manhã e noite } \\
\text { e medicação }\end{array}$ & Brincadeiras \\
\hline P6 & Conversam & Legal & Medicação e & Tratamento \\
\hline P7 & Conversam & Alegre & Ajuda e & Tratamento \\
\hline
\end{tabular}




\begin{tabular}{|c|c|c|c|c|}
\hline P8 & Conversam & Breve & Visita & Tratamento \\
\hline P9 & Conversam & Breve & $\begin{array}{c}\text { Técnica e } \\
\text { relatório }\end{array}$ & Tratamento \\
\hline P10 & Conversam & Acalmar & Medicação e & $\begin{array}{c}\text { Tratamento, } \\
\text { família, } \\
\text { visita }\end{array}$ \\
\hline P11 & Não & Não & Não & profissão \\
\hline P12 & Conversam & Breve e & Refeições & Brincadeiras \\
\hline P13 & Conversam & Amigável & Pátio & Tratamento \\
\hline P14 & Conversam & Breve & Pátio & Tratamento \\
\hline P15 & Conversam & Alegre & Postinho & Brincadeiras \\
\hline
\end{tabular}

Quadro 4 Categoria 2- Conteúdo e circunstâncias da interação

\begin{tabular}{|c|c|}
\hline ENTRA EM CONTATO (13) & $\begin{array}{l}\text { “... entra e conversa" / " } \\
\text {....conversam"/ " ...conversam } \\
\text { pouco" /" }\end{array}$ \\
\hline NÃO ENTRAM EM CONTATO (2) & “ ...não” \\
\hline TIPO DE CONVERSA (14) & 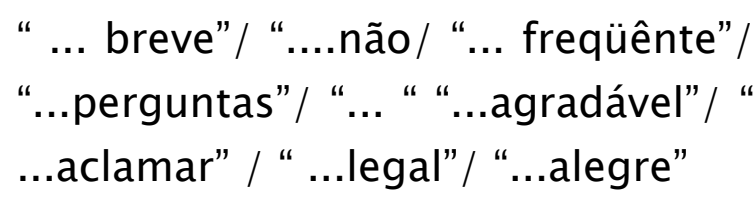 \\
\hline SITUAÇÕES DA CONVERSA (19) & $\begin{array}{l}\text { “... medicação" / “ ....visita”/ “ } \\
\text {...técnica”/ “...pátio”/ “...relatório”/ “ } \\
\text {....postinho"/ }\end{array}$ \\
\hline CONTEÚDO DA CONVERSA (18) & $\begin{array}{l}\text { “... tratamento" / " ....brincadeira" / “ } \\
\text {...não"/ "...família" / “...comida”/ “ }\end{array}$ \\
\hline
\end{tabular}


Dos quinze pacientes entrevistados, doze (12) responderam que a enfermagem conversa com eles, um (01) respondeu que conversa pouco, e dois (02) relataram que não conversam. Para Travelbee (1982), é tarefa do enfermeiro estimular o paciente a se expressar verbalmente, o que permite ao outro conhecer-se melhor e possibilita experimentar novos comportamentos.

Quando questionados sobre o tipo desta conversa, seis pacientes relataram tratar-se de uma conversa breve, um disse que é em forma de perguntas sobre o tratamento dele, P5 informou ser uma conversa agradável sempre relacionada com brincadeiras, P7 e P15 disseram ser alegre, P6 que é legal e P13 que esta é amigável e P10 que é uma conversa que acalma.

“Conversam, eles perguntam como é que passou”(P8).

“Agradável e é sempre assim... em torno da doença”(P6).

"Isso depende, se elas estiverem muito apertadas demora só um pouquinho”(P4).

Quando observa-se no quadro as situações em que ocorrem as conversas, nota-se que nos pacientes de clínica médica e cirúrgica ela está sempre relacionada à realização de técnicas e procedimentos, ou seja, na área instrumental. Nos psiquiátricos ocorre nos momentos de refeições, no pátio ou no posto de enfermagem. De qualquer forma observa-se que são conversas superficiais, descompromissadas, até mesmo mecânicas, coincidentes com outras atividades, refeição, medicação, lazer, e outras, portanto não existe um momento em que a 
conversa ocorra somente com a finalidade de ser terapêutica, com o objetivo de ajudar o paciente.

“...ela entra para trazer o medicamento, e para também as vezes perguntar como é que eu tô, se estou sentindo bem”(P2).

“entra, conversa, mede pressão, dá remédio pro coração, tudo”(P5).

“... para ajudar o paciente, trazer remédio...”(P7).

"É muito pouco contato. O nosso contato é na hora da janta , do lanche"(P12).

“É na hora que eu tô jogando paciência, aí eles chegam e conversam"(P14).

Matos (1995), relata que o momento da execução do cuidado é também uma oportunidade de relacionamento entre a enfermagem e o paciente, o que o torna responsável pelo sucesso da assistência.

Alguns pacientes justificaram a ocorrência de pouca conversa alegando pouco tempo disponível da enfermagem e falta de atenção da equipe.

Com relação ao conteúdo das conversas, nove pacientes disseram ser sobre o tratamento deles, ou seja alguma coisa sobre sua doença. Quatro responderam que estas conversas são sobre brincadeiras, e um ainda relatou que se fala sobre família, comida e profissão. Mais uma vez se reforça o fato de ser uma conversa técnica e mecânica, direcionada ao tratamento. Sobre o conteúdo ser brincadeiras entende-se que este conteúdo é bom por deixar o paciente mais alegre, tornar o ambiente hospitalar mais agradável e assim ser mais suportável aquele tratamento em que o paciente está sendo submetido. Por outro lado, essas brincadeiras poderiam ser uma forma dos profissionais de enfermagem não se envolverem, evitando assim uma conversa mais profunda, terapêutica com o 
paciente. Poderiam ser também por falta de conhecimento e não saberem como conduzir uma conversa.

Sabe-se que não é incomum que muitos profissionais desconhecem como iniciar uma conversação e como mantê-la de forma criativa. O estudo realizado por Waldow (1998), com pacientes internados em clínica cirúrgica, mostra pouca crítica sobre o cuidado técnico; não que ele não seja importante, mas parece inerente à profissão. Já o cuidado humano, a demonstração de afeto, o interesse foram bastante enfatizados. Ainda este estudo mostra também que algumas cuidadoras parecem se envolver, se interessar e se dedicar mais aos pacientes, sendo assim mais solicitadas por estes e seus familiares. Isto leva a indagar se este fato ocorre apenas por serem estas cuidadoras mais sensíveis e terem mais experiência, não só profissional, como também de vida, e não somente uma proposta real de trabalho.

Quadro 5 Respostas dos pacientes de como são tratados pelos técnicos e auxiliares de enfermagem.

\begin{tabular}{|c|l|}
\hline Paciente & \multicolumn{3}{|c|}{ Como é tratado pela enfermagem? } \\
\hline P1 & Eles conversam com delicadeza, bem \\
& educados. \\
\hline P2 & Até agora eu fui bem tratada pela \\
& enfermagem... \\
\hline
\end{tabular}




\begin{tabular}{|c|c|}
\hline P3 & Trata muito bem. \\
\hline P4 & Bem. \\
\hline P5 & Trata muito bem. \\
\hline P6 & Eu diria muito bem. Eles são atenciosos... \\
\hline P7 & $\begin{array}{l}\text { Tratam muito bem. Eu sou sempre bem } \\
\text { recebido. }\end{array}$ \\
\hline P8 & $\begin{array}{l}\text { Eles tratam a gente muito bem, graças a } \\
\text { Deus. }\end{array}$ \\
\hline P9 & $\begin{array}{l}\text { Eles fazem cara boa para a gente... Não } \\
\text { maltrata... }\end{array}$ \\
\hline P10 & Super bem. \\
\hline P11 & Tratam bem... Não dão atenção. \\
\hline $\mathrm{P} 12$ & Sou mais ou menos bem tratado. \\
\hline P13 & Muito bem. \\
\hline P14 & Me trata bem, tudo normal, tudo certinho. \\
\hline P15 & Trata muito bem. \\
\hline
\end{tabular}

Quadro 6 Categoria 3- Percepção do tratamento oferecido pelos técnicos e auxiliares de enfermagem.

\begin{tabular}{|c|c|}
\hline $\begin{array}{l}\text { INTERAÇÃO POSITIVA } \\
(12)\end{array}$ & $\begin{array}{l}\text { "... trata muito bem" / " ....conversam com } \\
\text { delicadeza" / "....são atenciosos"/ "... faz } \\
\text { cara boa"/ "....não maltrata" / "...não é } \\
\text { tratamento cinco estrelas"/ }\end{array}$ \\
\hline $\begin{array}{l}\text { INTERAÇÃO NEGATIVA } \\
\text { (4) }\end{array}$ & $\begin{array}{l}\text { “... tratam bem e não dão atenção" / “... } \\
\text { sou mais ou menos bem tratado" / “... } \\
\text { podia melhorar"/ }\end{array}$ \\
\hline
\end{tabular}


De acordo com os quadros 5 e 6, evidencia-se que dos quinze pacientes entrevistados, um respondeu ser super bem tratado, sete muito bem tratados, seis bem tratados, inclusive um deles (P1) refere que "eles conversam com delicadeza e bem educados”, e, outros pacientes relatam que,

“... eles fazem cara boa pra gente e conversa. Não maltrata a gente, não conversa com a gente de cara ruim, conversa satisfeita, alegre”(P9).

"Inteirou duas vezes que eu tô aqui, nunca fui mal tratado por ninguém, nunca tive que reclamar"(P8). educado”(P15).

"Os da enfermagem não tem nenhum bruto pra mim, são tudo

Poderia-se pensar que estes pacientes, oriundos de uma classe econômica baixa, ficam satisfeitos na forma como são tratados apenas pelo fato da equipe ter “cara boa” ou simplesmente não maltratá-los. Tratar com educação e respeito é ou pelo menos deveria ser o mínimo obrigatório no tratamento com qualquer pessoa, ainda mais se tratando de uma pessoa doente, hospitalizada, e com necessidade de assistência pelo serviço de saúde.

E apenas um paciente (P12) informa ser mais ou menos bem tratado, conforme no trecho seguinte:

E- E só o pessoal da enfermagem como é que eles te tratam? ...

P12- Uai... Não é aquele tratamento cinco estrelas.

E-Sei...

P12- Sou mais ou menos bem tratado.

E- Mais ou menos bem tratado?

P12- É, podia melhorar.

E- Você acha que precisava melhorar no quê?

P12- Tinha que dar mais atenção. A gente chega ali na porta, vai fazer uma pergunta eles viram as costas pra gente. Não liga, tem que ficar chamando. E eu sou educado, eu sempre peço por favor. Tem dia que eu chego ali vou perguntar alguma coisa eles não dão bola e saem. Às vezes eu preciso de alguma coisa e eles saem. Aí eu também saio se não eu fico nervoso. 
Em um estudo realizado por Waldow (1998), os pacientes relataram como atributos necessários ao cuidador atitudes como: paciência, atenção e carinho.

Entende-se que para tratar bem uma pessoa é necessário dar atenção ao que ela fala, e as suas necessidades. Não é possível tratar bem se ouvir o que a pessoa está perguntando ou verificar o que está precisando. A fala do P11 evidencia essa incoerência conforme se observa a seguir:

"Tratam bem. Elas não dão atenção. Até eu fui conversar com um enfermeiro que estava conversando com elas e elas mandaram eu sair.”

Percebe-se uma contradição neste discurso (P11) quando relata que "trata bem, mas é mal educado” demonstrando que há por parte do entrevistado receio de expressar sua percepção real sobre o tratamento, denotando possivelmente o medo de não ser cuidado ou de sofrer "retaliações”. Assim, o "poder" da equipe sobre o paciente fica implícito no seu discurso, como o paciente é psiquiátrico mostra como este paciente tem medo do castigo, que é o grande ameaçador. Isso nos revela que se por um lado existe um discurso de desinstitucionalização e humanização do atendimento, ainda persiste, como “pano de fundo,” a repressão, a ameaça, o poder sobre a doença e o doente.

Silva et al. (2001) descrevem em seu estudo com pacientes, que estes expressaram que esperam ser atendidos nas suas necessidades, sendo que, para isso, desejam que seus chamados sejam atendidos imediatamente após solicitação. 
Quadro 7 Respostas dos pacientes de como a conversa ajuda no seu tratamento.

\begin{tabular}{|c|c|}
\hline Pacientes & Como a conversa ajuda no tratamento \\
\hline $\mathrm{P} 1$ & Valorizando e melhorando. \\
\hline $\mathrm{P} 2$ & Anima. \\
\hline P3 & Anima. \\
\hline P4 & Ajuda. \\
\hline P5 & Anima. \\
\hline P6 & Anima. \\
\hline P7 & Alegra e anima. \\
\hline P8 & Alegra. \\
\hline P9 & Dá uma força. \\
\hline P10 & Acalma, relaxa. \\
\hline P1 1 & la melhorar se acontecesse. \\
\hline P12 & Melhora. \\
\hline P13 & Ajuda. \\
\hline $\mathrm{P} 14$ & $\begin{array}{l}\text { Ajuda porque é bom para a cabeça da gente, } \\
\text { alivia. }\end{array}$ \\
\hline P15 & Distrai a memória. \\
\hline
\end{tabular}

Quadro 8 Categoria 4- Contribuições das conversas no tratamento. 


\begin{tabular}{|c|c|}
\hline $\begin{array}{l}\text { PERCEPÇÃO POSITIVA } \\
\text { (18) }\end{array}$ & 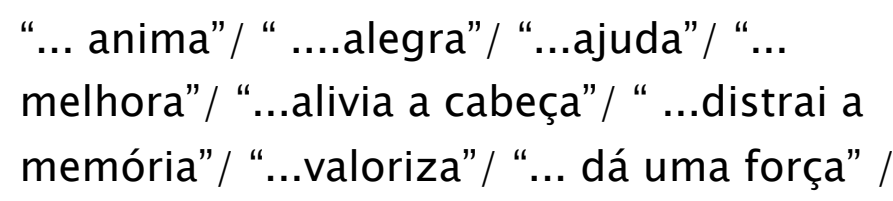 \\
\hline $\begin{array}{l}\text { PERCEPÇÃO NEGATIVA } \\
\text { (1) }\end{array}$ & "... ia melhorar se acontecesse" / \\
\hline
\end{tabular}

Segundo os quadro 7 e 8 quatorze pacientes responderam que a conversa com a enfermagem ajuda no seus tratamentos e um, que se ela acontecesse ia melhorar. Dentre os quatorze, seis deles afirmam que animam com este contato, dois citam que melhora ou alegra, que dá força, aclama, relaxa, alivia e distrai a memória. Os trechos a seguir ilustram melhor esta análise:

“... a gente tá vendo que aquela pessoa tá fazendo conta da gente. Tem atenção de conversar com a gente. Só da pessoa ir conversando com a gente, parece que a gente vai panhando uma melhora” (P1).

“Anima mais... a recuperação é mais fácil” (P2).

“...eles estando conversando com a gente e mostrando uma cara satisfeita a gente também fica” (P9). (P14).

"Ajuda porque é bom pra cabeça da gente, alivia o que a gente tá sentindo"

Embora os pacientes busquem cada vez mais uma atenção carinhosa e sensível, as exigências comerciais têm levado os profissionais de saúde à uma atenção pouco humana, mesmo sabendo que o atendimento das necessidades emocionais do paciente o deixa mais satisfeito e influenciam favoravelmente a uma melhora mais rápida. Sabe-se que todo sentimento de "amor” faz bem a saúde, portanto observa-se que o paciente ao perceber esse sentimento, quando cuidado, ele consequentemente sentirá que está sendo valorizado e beneficiado com a assistência (RIBEIRO, 2002). 
Quadro 9 Respostas dos pacientes sobre como eles se sentem quando técnicos ou auxiliares de enfermagem conversam com eles.

\begin{tabular}{|c|l|}
\hline Paciente & \multicolumn{1}{|c|}{\begin{tabular}{c}
\multicolumn{1}{c|}{ Sentimentos quando alguém da enfermagem } \\
conversa
\end{tabular}} \\
\hline P1 & $\begin{array}{l}\text {.. bem melhor. Parece que o coração da gente } \\
\text { alegra mais. }\end{array}$ \\
\hline P2 & $\begin{array}{l}\text { Me sinto bem, ... a gente vê que eles estão } \\
\text { preocupados. }\end{array}$ \\
\hline P3 & Eu sinto normal. É melhor, eu sinto bem. \\
\hline P4 & Sinto melhor porque distrai. \\
\hline P5 & Eu sinto mais animada. \\
\hline P6 & Eu me sinto bem. \\
\hline P7 & Sinto muita alegria e sinto melhor. \\
\hline P8 & Sinto muito bem, graças a Deus. \\
\hline P9 & Eu sinto satisfação e sinto que as coisas estão \\
\hline
\end{tabular}




\begin{tabular}{|l|l|}
\hline & melhorando. \\
\hline P10 & Sinto mais relaxada, fico menos nervosa. \\
\hline P11 & Eu ia sentir muito bem se acontecesse. \\
\hline P12 & $\begin{array}{l}\text { Levanta o astral porque dá mais atenção pra } \\
\text { gente. }\end{array}$ \\
\hline P13 & Eu sinto muito bem porque eles são muito bons. \\
\hline P14 & $\begin{array}{l}\text { A gente sente um alívio porque sente que tá sendo } \\
\text { bem tratado. }\end{array}$ \\
\hline P15 & Eu fico com alegria. \\
\hline
\end{tabular}

Quadro 10 Categoria 5 - Sentimentos do paciente frente à comunicação com os técnicos e auxiliares de enfermagem.

\begin{tabular}{|c|c|}
\hline SATISFAÇÃO (14) & 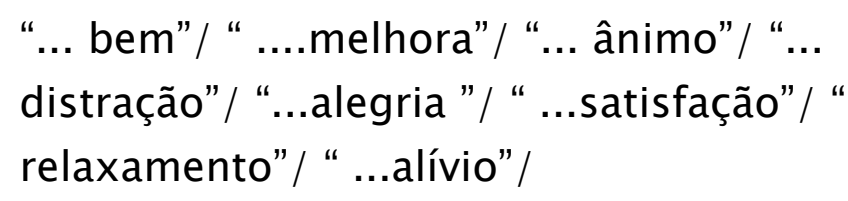 \\
\hline INSATISFAÇÃO (1) & "... ia sentir muito bem se acontecesse." \\
\hline
\end{tabular}

Quatorze pacientes responderam que a conversa com a enfermagem lhes desperta satisfação cinco responderam que se sentem bem, três que se sentem melhor quando conversam com a enfermagem, e outros três que essa conversa provoca alegria, que se sentem mais relaxados, valorizados, que distraem, ou que ficam satisfeitos.

Um paciente (P14) respondeu que fica aliviado por ser bem tratado. Essa resposta demonstra mais uma vez o medo que as pessoas têm de serem maltratados 
ou se depararem com auxiliares e técnicos de enfermagem mal-educados. A exigência por parte da maioria dos usuários de um serviço de saúde, principalmente público, é muito pequena. Quando um paciente faz um pedido ou reclamação pertinente à uma situação este deveria ser atendido prontamente, ou pelo menos deveria ser-lhe dado um motivo do porque isto não ocorreu. O paciente treze (P13) relatou que:

“Eu sinto muito bem porque eles são muito bons. Tem um que é muito bom. Eu vou reclamar as coisas pra ele e ele resolve na hora. Aqui eu sinto muito bem, não tenho nada a reclamar."

A paciente onze (P11) expressou sua insatisfação e desejo de que alguém da enfermagem conversasse com ela conforme trecho:

"Eu ia sentir muito bem. Toda vez que eu vou conversar com elas, elas acham que eu estou doente e eu não estou. Ninguém vem conversar comigo, elas falam: sai daqui porque senão eu vou errar."

Apesar de nem sempre se queixarem, os pacientes P11, P13 e P14 mostraram claramente a forma desumana que muitas vezes o paciente psiquiátrico é tratado, evidencia a necessidade de reflexão sobre a atuação profissional da enfermagem, a necessidade de se buscar novas formas de atendimento, de desenvolver a habilidade de lidar com as pessoas, e de tratar o outro com o respeito que gostaria de ser tratado.

A paciente P11 queixou-se da enfermagem, que a considera doente. Entende-se que a saúde mental das pessoas varia muito, de acordo com os momentos, e as situações vividas e questiona-se também a avaliação dos pacientes de acordo com a sua saúde mental, feita pelos técnicos e auxiliares de enfermagem devido ao pouco contato que estes têm com eles, e desta forma o pouco diálogo. Deste modo, a comunicação enquanto instrumento terapêutico parece-nos distante da prática dos 
técnicos e auxiliares de enfermagem, na medida em que estão permeados por qualificativos preconceituosos, pejorativos, dirigidos, principalmente aos portadores de sofrimento psíquico.

Quadro 11 O que os pacientes mais valorizam para o seu bem estar.

\begin{tabular}{|c|l|}
\hline Pacientes & \multicolumn{1}{|c|}{ Paciente mais valoriza para o seu bem estar } \\
\hline P1 & Se tivesse a conversa a gente sentiria mais \\
aliviada. & \\
\hline P2 & Eu acho que mais é o diálogo... Eles serem \\
& educados... \\
\hline P3 & Mais importante é saber como a gente tá \\
& passando... \\
\hline
\end{tabular}




\begin{tabular}{|c|c|}
\hline P4 & O tratamento,... é o remédio... \\
\hline P5 & $\begin{array}{l}\text { O que eu dou mais valor aqui dentro são os } \\
\text { enfermeiros. }\end{array}$ \\
\hline P6 & Acho que são os remédios. \\
\hline P7 & Ser bem tratado. \\
\hline P8 & Tudo tá envolvido. \\
\hline P9 & $\begin{array}{l}\text { Ser bem recebido por todos. Pela enfermagem, } \\
\text { todos. }\end{array}$ \\
\hline P10 & $\begin{array}{l}\text {...só deles deixarem a gente a vontade já é } \\
\text { muito importante. }\end{array}$ \\
\hline P11 & É conversar com os outros... \\
\hline $\mathrm{P} 12$ & $\begin{array}{l}\text { Eu acho que se eles dessem mais atenção pra } \\
\text { gente. }\end{array}$ \\
\hline P13 & $\begin{array}{l}\ldots \text { o almoço,...chuveiro...tudo limpinho, os } \\
\text { funcionários tratam a gente muito bem. }\end{array}$ \\
\hline P14 & $\begin{array}{l}\text { É a amizade com todo mundo, com os colegas e } \\
\text { com a enfermagem. }\end{array}$ \\
\hline P15 & $\begin{array}{l}\text {...é quando a T.O. está aberta, ocupa o } \\
\text { tempo...pra mim é uma alegria. }\end{array}$ \\
\hline
\end{tabular}


Quadro 12 Categoria 6 - Aspectos que contribuem para o bem estar do paciente.

\begin{tabular}{|c|c|}
\hline COMUNICAÇÃO (3) & “... conversa” / “ ....diálogo”/ \\
\hline ATITUDE (7) & $\begin{array}{l}\text { “...saber como a gente ta } \\
\text { passando” / “... ser bem tratado”/ } \\
\text { “... tudo ta envolvido” / “...ser bem } \\
\text { recebido por todos”/ “...deixam a } \\
\text { gente a vontade” / “...mais } \\
\text { atenção” / “....amizade com todo } \\
\text { mundo” / “...serem educados”/ }\end{array}$ \\
\hline TERAPIAS ALTERNATIVAS (1) & “... quando a TO está aberta"/ \\
\hline ASSISTÊNCIA INSTRUMENTAL (5) & $\begin{array}{l}\text { “... tratamento" / “ ....remédio" / " } \\
\text {...almoço" / “ ...chuveiro"/ } \\
\text { “...funcionários"/ }\end{array}$ \\
\hline RECURSOS HUMANOS (4) & “...enfermagem”/ \\
\hline
\end{tabular}

Observa-se que das quinze respostas dadas, nove delas, P1, P2, P3, P7, P9, P10, P12, P13 e P14, relatam conteúdos relacionados á comunicação e relacionamento interpessoal. Em um estudo realizado por Silva et al. (2001) os 
pacientes expressaram carinho, paciência e educação como manifestações de cuidado, eles esperando que o cuidador tivesse disposição para atendê-los em suas necessidades como ser humano.

A compreensão sobre como entender a forma de pensar do outro ajuda a evitar atritos e solucionar problemas, promovendo, assim, relações saudáveis, onde a sinergia, o respeito e a empatia estão presentes. Com o advento da globalização e da forte competitividade, o que conta hoje no mundo do trabalho não são apenas os seus conhecimentos técnicos, mas também talento laboral e idéias criativas. É importante, também, desenvolver a sua capacidade de interagir construtivamente com pessoas que estão inseridas em seu meio profissional ( MEDEIROS, 2005).

Constata-se assim, a valorização dos pacientes na forma como são tratados, dois pacientes ainda reforçaram a importância atribuídos a enfermagem conforme a resposta do paciente nove (P9) e quatorze (P14) e no trecho descrito abaixo, segundo a fala do paciente cinco (P5):

“...você não vê nenhum entrando aqui de cara ruim...ás vezes eles medicam um, outro, corre, vem na cama da gente e brinca, conversa com a gente e quando eles saem a gente fica mais alegre. È bom demais”.

Moscovici (1993) também enfatiza o valor de se tratar bem os clientes e comenta que a competência interpessoal é a habilidade de lidar eficazmente com relações interpessoais, de lidar com outras pessoas de forma adequada às necessidades de cada um e às exigências da situação.

É necessário argumentar as idéias com firmeza e entusiasmo, porém, deve-se observar a educação, respeito, equilíbrio emocional, falar menos e ouvir mais. Atualmente, não basta apenas expandir conhecimentos técnicos e habilidades. É vital saber proteger, com educação, seus interesses em seus relacionamentos, fazer 
seu marketing pessoal, mas também agir com ética, sinergia em equipe e respeito a qualquer pessoa que esteja engajada em sua vida profissional (MEDEIROS, 2005).

Uma boa comunicação é essencial na relação interpessoal. As relações devem ser cultivadas e estabelecidas da melhor maneira possível, principalmente, em ambientes onde o cuidado e o atendimento às pessoas fragilizadas são os principais enfoques. A qualidade e a humanização do atendimento estão diretamente relacionadas com a afetiva comunicação (verbal e não verbal).

Assim, considerando o agrupamento na categoria 6, aparece com freqüência importante a valorização do cuidado instrumental em relação ao expressivo.

A seguir, no quadro 13, apresenta-se os recortes do discurso dos pacientes com relação às sugestões que possam melhorar a assistência de enfermagem.

Quadro 13 Sugestões dos pacientes para melhorar assistência de enfermagem.

\begin{tabular}{|c|l|}
\hline Paciente & \multicolumn{1}{|c|}{ Sugestões } \\
\hline P1 & Não, já tá bom. \\
\hline P2 & $\begin{array}{l}\text { Serem sempre educados com o } \\
\text { paciente, ter bastante diálogo... }\end{array}$ \\
\hline P3 & Não, só agradecimento. \\
\hline P4 & Mais remédios, mais doutor. \\
\hline P5 & Pra mim não tem nada que mudar. \\
\hline P6 & Pode ser que exista, mais eu acho que \\
tá muito bom assim. \\
\hline P7 & Não, não sei. \\
\hline P8 & Eu acho que o que vocês podem fazer \\
\hline
\end{tabular}




\begin{tabular}{|c|l|}
\hline & vocês fazem, não precisa nem pedir. \\
\hline P9 & $\begin{array}{l}\text { Tem que estudar bastante para poder } \\
\text { melhorar e fazer as coisas bem feitas. }\end{array}$ \\
\hline P10 & $\begin{array}{l}\text { Continuando assim tá bom... o } \\
\text { tratamento aqui tá bom. }\end{array}$ \\
\hline P11 & Não. \\
\hline P12 & Separar as internações por patologias. \\
\hline P13 & Melhorar mais aqui não precisa... Pra \\
\hline n14 & nossa classe não. \\
\hline P15 & Separar as internações por patologias. \\
\hline & Não. \\
\hline
\end{tabular}

Quadro 14 Categoria 7 - Sugestões destacadas para melhorar a assistência de enfermagem.

\begin{tabular}{|c|c|}
\hline SEM ALTERAÇÕES (8) & 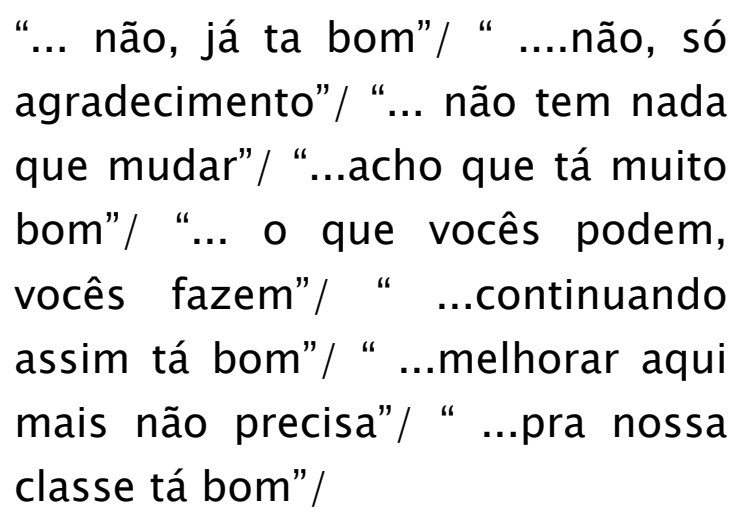 \\
\hline INTERAÇÃO/COMUNICAÇÃO (1) & “...ter bastante diálogo"/ \\
\hline SEM POSICIONAMENTO (3) & “... não, não sei”/ “...não”/ \\
\hline CLASSIFICAÇÃO DA DOENÇA (2) & “... separar as internações por \\
\hline
\end{tabular}




\begin{tabular}{|l|l|}
\hline & patologias" / \\
\hline TRATAMENTO (2) & "... mais remédios" / " ...mais \\
& médicos" / \\
CAPACITAÇÃO (1) & “... estudar bastante... pra fazer as \\
& coisas bem feitas" / \\
\end{tabular}

Nestas respostas, oito pacientes relataram que não precisa mudar nada (P1, P3, P5, P6, P7, P10, P11 e P15), isto reforça o entendimento de que os pacientes têm receios de desagradar ou de reclamar do serviço, e serem penalizados, não cuidados, conforme a fala do paciente P8, que considera a assistência prestada a eles boa, já por pertencerem à uma classe social mais baixa (P13). Denota também o conformismo desses pacientes, que revelam a concepção que a população menos favorecida sócio economicamente faz do Sistema Único de Saúde (SUS), como um modelo que veio para atender apenas o pobre, assim, qualquer benefício a mais oferecido, torna-se, para este usuário, motivo de reverência ao profissional que o atende.

Os pacientes têm uma tendência a enxergar o profissional de saúde com propriedades poderosas e onipotentes, semelhantes às que as crianças acham que os pais possuem, quando ainda responsáveis por elas e por seu cuidado. O paciente sente-se pequeno, desamparado e à mercê do profissional; a crença no poder do profissional permite-lhe sentir-se seguro na situação de perigo (MARTINS, 1996). 
Isso difere da fala do paciente nove (P9), quando, tratando de uma forma generalizada sugeriu que os profissionais de enfermagem estudassem bastante para melhorar a assistência. Autores como Takahashi e Fernandes (2001), afirmam que o ensino de enfermagem deve prover condições sustentáveis para o aluno incorporar novos conhecimentos e valores, rompendo com o ato mecânico, permeados pela humanização e por condutas éticas daquele que assiste para aquele que é assistido.

Sabe-se que várias mudanças têm sido feitas nos currículos dos cursos de enfermagem, o que sem dúvida é um avanço, mas, ainda há muito que se mudar na formação dos auxiliares e técnicos de enfermagem, que é extremamente tecnicista e que ainda hoje, enfatiza pouco o relacionamento interpessoal como uma habilidade que tem que ter fundamentos teóricos e exercício prático contínuo. É também necessário que a filosofia das instituições mudem na valorização dos recursos humanos e na educação permanente dos profissionais de saúde, pois, não basta oferecer isto na formação escolar se não houver perpetuação e aperfeiçoamento constante dos profissionais.

Constata-se também a insatisfação dos pacientes alcoolistas (P12 e P14) em serem tratados no mesmo ambiente físico que outros pacientes portadores de transtornos psiquiátricos.

A seguir, os resultados das observações, serão apresentados na íntegra, conforme foram registrados, por serem seus conteúdos sintéticos, tendo em vista o pouco contato estabelecido pelos auxiliares e técnicos de enfermagem com os pacientes. A forma destacada mostra descritivamente o registro feito e posteriormente, os quadros 8, 9 e 10 apresentam uma síntese para melhor visualização. 


\section{Observações da Clínica Médica}

Enfermaria M1: Foram observadas três pacientes $(1,2,3)$ e o auxiliar de enfermagem entrou duas vezes no quarto, todas por iniciativa própria..

- A auxiliar de enfermagem entrou uma vez no quarto, trocou a fralda da paciente, acomodou-a, e saiu.

- Duas auxiliares de enfermagem entraram no quarto, cumprimentaram dizendo "boa tarde”, e saíram.

Enfermaria M2: Observadas três pacientes $(4,5,6)$ e o auxiliar de enfermagem entrou uma vez no quarto, por iniciativa própria.

- Auxiliar de enfermagem entrou apenas uma vez, explicou que iria retirar o jelcro (acesso venoso), pois as medicações seriam via oral, e saiu.

Enfermaria M3: Observados três pacientes masculinos $(7,8,9)$ e o auxiliar de enfermagem entrou três vezes no quarto , todas por iniciativa própria..

- O auxiliar de enfermagem passou visita, perguntou a cada paciente desta como estava passando e saiu.

- O auxiliar de enfermagem entrou, perguntou se estava tudo bem, fez uma insulina subcutânea e saiu.

- O auxiliar de enfermagem perguntou pelo nome do paciente porque ia fazer uma medicação. Pediu para este se sentar para fazer o "remedinho" para a dor. Fez a medicação endovenosa, o paciente perguntou qual era a medicação que estava sendo feita e este respondeu que era o zylium. O paciente perguntou se estava adiantada a medicação, o funcionário respondeu que sim, e ao terminar o procedimento disse que estava pronto, e saiu.

Enfermaria M4: Foram observados três pacientes masculinos $(10,11,12)$ e o técnico ou o auxiliar de enfermagem entrou cinco vezes no quarto, todas por iniciativa própria.

- O auxiliar de enfermagem entrou na enfermaria mas não verbalizou nada com os pacientes e nem com os acompanhantes.

- Uma auxiliar de enfermagem entrou na enfermaria, verificou o gotejamento do soro de um paciente, sem nada verbalizar, e saiu.

- O técnico de enfermagem entrou na enfermaria, perguntou se o paciente precisava de alguma coisa enquanto verificava o gotejamento do soro. No segundo paciente, apenas verificou o gotejamento do soro. Com o terceiro paciente nenhum procedimento foi realizado nem falou-se nada.

- O técnico de enfermagem entrou novamente no quarto, verificou o soro de um paciente, perguntou a este se estava "tudo certinho", o mesmo pediu para abaixar a 
cabeceira da cama, o funcionário abaixou, perguntou se estava bom e se ele não estava com "falta de ar", o paciente respondeu que não e o funcionário saiu.

- O técnico de enfermagem entrou para fazer uma medicação endovenosa, perguntou se a veia estava doendo, o paciente respondeu que não então o funcionário diz que estava fazendo um antibiótico e que se doesse era pra ele avisá-lo. Controlou o gotejamento do soro, se despediu dizendo que qualquer coisa para lhe chamar, e saiu.

Enfermaria M5: Foram observadas três pacientes femininas $(13,14,15)$ e o técnico ou o auxiliar de enfermagem entrou três vezes no quarto, sendo uma por iniciativa própria e duaspor iniciativa do acompanhante.

- A técnica de enfermagem entrou no quarto para se despedir dos pacientes e acompanhantes pois seu plantão tinha terminado.

- A acompanhante chamou a auxiliar de enfermagem orientou a outra acompanhante para não dar nada via oral já que a paciente estava com sonda naso-entérica.

- A acompanhante chamou a auxiliar de enfermagem porque a dieta da sonda nasoentérica já tinha acabado. Esta desligou a dieta, aproveitou para controlar o gotejamento do soro e perguntou à acompanhante se a paciente estava tomando alguma coisa na veia. A mesma respondeu que não e a auxiliar de enfermagem saiu.

Enfermaria M6: Foram observadas três pacientes femininas $(16,17,18)$ e o técnico ou o auxiliar de enfermagem entrou quatro vezes no quarto, sendo três por iniciativa própria e uma por iniciativa do acompanhante.

- A técnica de enfermagem avisou a paciente que iria trocar a fralda. Pediu ajuda á acompanhante e disse que mesmo tendo terminado seu horário ela iria trocá-la porque a fralda tinha acabado de chegar. Acomodou a paciente, verificou a temperatura porque a paciente estava com febre às 11 horas. A paciente começou a mexer na sonda naso-entérica e a técnica de enfermagem orientou para ela não mexer pois a sonda era para o bem dela.

- Outra acompanhante pediu a mesma funcionária que verificasse a pressão arterial da paciente, esta realizou o procedimento e disse que tinha abaixado um pouquinho. A funcionária perguntou à paciente se ela toma medicação em casa e explicou- lhe que devagar iria abaixando.

- A auxiliar de enfermagem ajudar a levar a paciente ao banheiro esta perguntou se ela não queria fazer na fralda, ela respondeu que não. Assim a auxiliar de enfermagem levou a paciente ao banheiro, retirou a fralda, aguardou ter diurese, mas não verbalizou nem com a paciente nem com a acompanhante. Acomodou a paciente na cadeira e saiu.

- A auxiliar de enfermagem entrou, disse para a paciente que ia deitá-la para colocar o soro na bomba de infusão, e saiu.

Enfermaria M7: Observados três pacientes masculinos $(19,20,21)$ e a auxiliar de enfermagem entrou três vezes no quarto.

- A auxiliar de enfermagem chegou e cumprimentou muito rápido o paciente de alta, desligou o soro, disse para esperar porque está com um jelcro mais calibroso. Retirou o soro e que iria sangrar muito depois saiu. 
- Auxiliar de enfermagem chegou, só trocou a dieta, chamou-o pelo nome, mais nada.

- Auxiliar de enfermagem chegou, conversou com o paciente, chamando pelo nome, cumprimentou.

Enfermaria M8: Observados três pacientes masculinos $(22,23,24)$ e a auxiliar de enfermagem entrou cinco vezes no quarto.

-Entrou uma auxiliar de enfermagem olhou e saiu.

- Auxiliar de enfermagem entrou, cumprimentou um paciente, passou a mão na cabeça dele(paciente) e saiu.

- Auxiliar de enfermagem entrou, verificou o gotejamento do soro do primeiro paciente, conversou com o segundo paciente, perguntou se ele melhorou, retirou o ar do frasco de soro, posicionou o terceiro paciente, colocou um travesseiro debaixo de sua perna e saiu.

- Auxiliar de enfermagem entrou e colocou um travesseiro debaixo da cabeça o primeiro paciente e lhe explicou que assim ele não teria dor no pescoço. Disse que se precisar de algo é só chamar. Trocou a água do copo de oxigênio do terceiro paciente e saiu.

- Auxiliar de enfermagem entrou, olhou o soro do primeiro paciente, a filha do terceiro paciente solicitou que ele fizesse tricotomia na face do pai dela e o auxiliar de enfermagem respondeu que fará. Depois ele saiu.

Quadro 15 Síntese das observações realizadas na clínica médica.

\begin{tabular}{|c|r|l|}
\hline Pacientes & Freqüência & \multicolumn{1}{|c|}{ Motivo do contato } \\
\hline $1,2,3$ & 2 vezes & - higiene e visita \\
\hline $4,5,6$ & 1 vez & - medicação \\
\hline $7,8,9$ & 3 vezes & - visita, medicação (2 vezes) \\
\hline $10,11,12$ & 5 vezes & - observação, medicação (4 vezes) \\
\hline $13,14,15$ & 3 vezes & - despedir, orientação, dieta e medicação \\
\hline
\end{tabular}




\begin{tabular}{|c|c|l|}
\hline $16,17,18$ & 4 vezes & $\begin{array}{l}\text { - hisita } \\
\text { medicação ssv, ssvv, higiene, orientar }\end{array}$ \\
\hline $19,20,21$ & 3 vezes & - orientação de alta, dieta e visita \\
\hline $22,23,24$ & 5 vezes & $\begin{array}{l}\text { - observação, visita, medicação e confort } \\
\text { conforto e oxigênio, medicação }\end{array}$ \\
\hline
\end{tabular}

Um hospital geral apresenta diferentes espaços que se distinguem pelo trabalho técnico produzido, prevalecendo algumas características que identificam cada tipo de clínica. No caso da clínica médica ocorre uma predominância pelos cuidados ou técnicas de higienização, dietoterapia, oxigenoterapia, sinais vitais (ssvv) e conforto. A observação destes e dos sinais e sintomas apresentados constituem a base em que os técnicos e auxiliares de enfermagem se fundamentam para avaliar a melhora e a recuperação do paciente, ou a regressão do quadro clínico, e por isso é freqüente o contato da enfermagem com os pacientes, já que estes necessitam de cuidados com diferentes complexidades (pequena, média ou alta).

Das vinte e seis vezes em que os técnicos e auxiliares de enfermagem entraram em contato com o paciente, quatro vezes a iniciativa ocorreu por solicitação do acompanhante do paciente, é o que se nota no segundo e terceiro registros de observação de M5 e no segundo de M6.

Evidencia-se também que mesmo ocorrendo o contato, muitas vezes este se deu de forma não verbal, conferindo se o paciente estava no leito ou não e o gotejamento do soro, quando necessário, ou no momento de passar visita. Este procedimento chamado de "corrida de leito", é uma das tarefas dos profissionais de nível médio de enfermagem no momento em que se inicia o plantão. 
O quadro evidencia que são raros os momentos de interação ou de relação interpessoal em que os técnicos e auxiliares de enfermagem aproximam-se do paciente apenas para ouví-lo ou conversar com ele. Chama a atenção o primeiro registro de observação de M5 no qual descreve uma técnica de enfermagem que entrou no quarto para se despedir dos pacientes, seu plantão já tinha terminado, já não era mais obrigação dela cuidar daqueles pacientes, mas a funcionária criou um vínculo de amizade com estes e seus acompanhantes. Silva et al. (2001) salientam que no momento em que os profissionais de enfermagem e paciente se aproximam nas situações de cuidado, estabelecem a relação interpessoal, que se dá quando ambos têm disposição para estar-com-o-outro.

\section{Observações da Clínica Cirúrgica}

Enfermaria C1: Foram observados três pacientes $(25,26,27)$ e a auxiliar de enfermagem entrou três vezes no quarto, sendo duas por iniciativa própria e uma por iniciativa do paciente.

- A auxiliar de enfermagem entrou no quarto, olhou os pacientes e saiu.
- O auxiliar de enfermagem entrou no quarto, disse "Boa tarde” á todos os pacientes,
cumprimentou com um aperto de mão um paciente, perguntou como ele estava
passando, se estava melhor, despediu do paciente dizendo para ele ficar com Deus e
saiu.
- A campainha do quarto tocou, a auxiliar de enfermagem entrou, perguntou o que
foi , o paciente respondeu que o soro estava acabando, ela controlou gotejamento. A
auxiliar de enfermagem perguntou ao outro paciente se ele tinha urinado, este
respondeu que não, ela disse que iria ajudá-lo, ele pediu um funcionário do sexo
masculino, ela disse que iria chamá-lo, depois retornou ao mesmo paciente
perguntando se ele não dava conta de segurar o papagaio porque aí ela iria entregá-
lo. O paciente aceitou, a auxiliar esperou o paciente terminar, desprezou a diurese
perguntou se estava bem assim e saiu.

Enfermaria C2: Foram observados três pacientes $(28,29,30)$ e o técnico ou o auxiliar de enfermagem entrou duas vezes no quarto, sendo uma por iniciativa própria e uma por iniciativa do acompanhante.

- A auxiliar de enfermagem entrou no quarto, olhou os pacientes, abriu o armário e saiu.

- A acompanhante chamou a técnica de enfermagem para ver um curativo que tinha sangrado, ela posicionou a paciente e disse que não iria trocar o curativo porque 
tinha feito a cirurgia naquele dia e a conduta era trocar no outro dia. Acomodou a paciente no leito colocando travesseiro e mantendo o pé esquerdo elevado, orientou a acompanhante que o pé deveria ficar naquela posição e saiu.

Enfermaria C3: Foram observados três pacientes $(31,32,33)$ e o auxiliar de enfermagem entrou três vezes no quarto, sendo uma por iniciativa própria e uma por iniciativa do paciente.

- Auxiliar de enfermagem passou no quarto, conversou rápido com as pacientes, perguntou como estavam passando e saiu.

- Outra auxiliar de enfermagem entrou no quarto e saiu.

- Paciente chamou a auxiliar de enfermagem, e esta perguntou o que precisava, a paciente respondeu que o soro está vazando, então ela controlou gotejamento e saiu.

Enfermaria C4: Foram observados três pacientes $(34,35,36)$ e o auxiliar de enfermagem entrou quatro vezes no quarto, sendo três por iniciativa própria e uma por iniciativa do paciente.

- Auxiliar de enfermagem passou uma visita, perguntando como o paciente está passando.

- Auxiliar de enfermagem entrou no quarto, abriu o armário, fechou e saiu.

- Paciente chamou a auxiliar de enfermagem e perguntou para ele o que precisava, verificou o soro e saiu.

- Auxiliar voltou, o paciente achou que o soro não estava correndo, ele disse para ela ver a incisão que ele acha que está vazando, mas não estava, ela disse que trocaria mais tarde.

Enfermaria C5: Foram observados três pacientes $(37,38,39)$ e o auxiliar de enfermagem entrou seis vezes no quarto, sendo cinco por iniciativa própria e uma por iniciativa do paciente.

- Auxiliar de enfermagem entrou, cumprimentou os pacientes, disse ao primeiro que ele ia tomar inalação, entregou a ele. Colocou termômetro no segundo paciente, explicou que era para ver a temperatura e disse que ia à farmácia e voltaria. Saiu.

- Auxiliar entrou, conferiu a pressão arterial do segundo paciente, perguntou à irmã do primeiro o porque da internação, ao que ela respondeu que era câncer. A auxiliar perguntou ao segundo paciente se ele sente alguma dor, ele disse que não. Ela perguntou ao primeiro paciente se ele era diabético ele disse que não; perguntou se ele era hipertenso, ele disse que sim, perguntou qual remédio ele toma, ele disse Propanolol. Perguntou se ele era alérgico a algum remédio e ele disse que não. Ela despediu e saiu.

- Auxiliar entrou, perguntou quem acionou a campainha, o paciente disse que estava com dor e saiu.

- Auxiliar entrou, fechou a porta, disse que ia fazer uma injeção para dor. Pediu licença, abaixou um pouco o shorte do paciente e aplicou a injeção no glúteo.

- Auxiliar de enfermagem entrou, explicou ao primeiro paciente que ia fazer uma medicação no tree- way, pergunta como ele estava, ele disse que estava preocupado com a glicose, estava com medo de abaixar muito, porque ele tomou injeção de 
insulina. Ela disse para ele ficar tranqüilo porque a médica estava fazendo o controle. Ele perguntou se tinha como acelerar o gotejamento do soro, ela disse que as gotas tinham a quantidade certa. Ela olhou o acesso venoso e disse que buscaria o esparadrapo para ficar melhor. Cumprimentou o segundo paciente e brincou com ele que logo ele irá embora. Saiu.

- Auxiliar entrou, fixou o jelcro na mão do primeiro paciente, perguntou se estava doendo, ele disse que não. Saiu.

Enfermaria C6: Foi observado um paciente (40) e o auxiliar de enfermagem entrou três vezes no quarto.

- Auxiliar de enfermagem entrou, olhou o gotejamento do soro, paciente queixou dor, disse que ela estava demorando com o remédio, ela saiu e disse que ia buscar comentou que estava demorando a acabar e saiu.

- Auxiliar entrou, explicou ao paciente que ia aplicar insulina, perguntou onde ele estava acostumado a fazer, ele disse que era na barriga. Então ela aplicou a insulina, disse que não ia doer. Perguntou se doeu, ele disse que não. Ela se despediu e saiu.

- Auxiliar entra, fechou soro porque acabou, disse ao paciente que iria ligar outro soro. Perguntou se ele viu onde estava a tampinha do tree- way e ele lhe mostrou. Ela conversa um pouco com ele, retirou o ar do equipo, perguntou se estava ardendo, controlou o gotejamento e saiu.

Enfermaria C7: Foram observados três pacientes $(41,42,43)$ e o auxiliar de enfermagem entrou cinco vezes no quarto, sendo quatro por iniciativa própria e uma por iniciativa do acompanhante.

- A auxiliar de enfermagem entrou no quarto, perguntou ao paciente por que ele estava sem soro, ele disse que era porque tinham tirado, então ela respondeu que ia colocar de novo para ele fazer mais "xixi” e o paciente sorriu e perguntou " mais ainda?", a auxiliar de enfermagem confirmou que sim. Perguntou ao outro paciente como estava o soro, ele disse que tudo bem. Passou para o paciente e controlou o gotejamento. Saindo do quarto disse que qualquer coisa era para chamar.

- A auxiliar retornou ao quarto porque o acompanhante chamou dizendo que o soro não estava pingando. Ela controlou gotejamento, disse que era bem lento, disse que estava pronto e saiu.

- A auxiliar de enfermagem veio controlar novamente o gotejamento do soro do paciente, perguntou por que ele ainda não tinha ido embora, ele respondeu que não sabia. A auxiliar de enfermagem, perguntou se ele já estava cansado do hospital, ele disse que sim. A auxiliar de enfermagem sorriu para ele e saiu. Outro paciente brincou que eles não estavam bem, a auxiliar de enfermagem sorriu e disse que naquele quarto estavam todos ótimos e saiu.

- Novamente entrou no quarto a auxiliar de enfermagem para controlar gotejamento do soro dos três pacientes, sem dizer nada.

- A auxiliar de enfermagem entrou sem dizer nada e entregou a medicação oral para o paciente, esperou ele tomar e saiu.

Enfermaria C8: Foram observados dois pacientes $(44,45)$ e o auxiliar de enfermagem entrou três vezes no quarto. 


\begin{abstract}
- A auxiliar de enfermagem entrou no quarto sorrindo, pedindo um pouco de paciência porque hoje está terrível o movimento na ala. Perguntou o nome do paciente, preparou material para instalar soroterapia, perguntou se ele estava com dor, este respondeu que sim, ela disse que iria medicá-lo. Orientou o paciente sobre a punção venosa, ele disse que as veias estavam ruins, ela disse que estavam boas e que em um instantinho já estaria pronto, pediu para ele não puxar a mão, controlou o gotejamento. Disse que estava pronto e já poderia relaxar a mão.

- A auxiliar de enfermagem perguntou o nome do outro paciente e disse que já voltaria com o soro dele.

- A auxiliar de enfermagem entrou, olhou os soros e saiu.
\end{abstract}

Enfermaria C9: Enfermaria com três pacientes $(46,47,48)$ e o auxiliar de enfermagem entrou três vezes no quarto, sendo uma por iniciativa própria e duas por iniciativa do paciente.

- A auxiliar de enfermagem entrou porque foi chamada pela acompanhante que informou que o soro tinha terminado, então ela desligou o soro e saiu.

- Auxiliar entrou porque o paciente tocou a campainha, perguntou o que ele precisava e ele disse que queria ir para a cama, a auxiliar disse que iria chamar uma colega para ajudar e saiu.

- A auxiliar e a enfermeira entraram, falaram para o paciente que o levariam da cadeira para perto da cama. Ele pegou debaixo dos braços do paciente e a enfermeira pegou nas pernas e o transportaram para a cama. O paciente agradeceu e elas saíram.

Quadro 16 Síntese das observações realizadas na clínica cirúrgica.

\begin{tabular}{|l|r|l|}
\hline Pacientes & Freqüência & Motivo do Contato \\
\hline $25,26,27$ & 3 vezes & - observação, visita, relatório \\
\hline $28,29,30$ & 2 vezes & - observação e conforto \\
\hline $31,32,33$ & 2 vezes & - visita e medicação \\
\hline
\end{tabular}




\begin{tabular}{|c|c|l|}
\hline $34,35,36$ & 4 vezes & - visita (2 vezes), observação, medicaçã \\
\hline $37,38,39$ & 6 vezes & $\begin{array}{l}\text { - inalação e ssvv, ssvv e história do pct } \\
\text { queixa dor, medicação (2 vezes), confo } \\
\text { (gêlo) }\end{array}$ \\
\hline 40 & 3 vezes & - medicação (3 vezes) \\
\hline $41,42,43$ & 5 vezes & - visita e medicação, medicação (4 veze \\
\hline 44,45 & 3 vezes & - visita e medicação (2 vezes), medicaç: \\
\hline $46,47,48$ & 3 vezes & $\begin{array}{l}\text {-acompanhante chamou (2 vezes), } \\
\text { transporte do paciente }\end{array}$ \\
\hline
\end{tabular}

No caso da clínica cirúrgica ocorreram uma predominância pelos cuidados ou técnicas de administração de medicação, principalmente analgésicos e soroterapia, curativos, atendimento às queixas de dor, observações de diurese, verificação dos sinais vitais (ssvv), entre outros. É através destes que os auxiliares e técnicos de enfermagem se baseavam para avaliar a melhora e recuperação do paciente, ou a regressão do quadro cirúrgico.

Das trinta e uma vezes os técnicos e auxiliares de enfermagem entraram em contato com o paciente, quatro vezes a iniciativa partiu do próprio paciente conforme o terceiro registro de observação de C1, o segundo de C3, o terceiro de C4 e C5. Quatro vezes a iniciativa partiu do acompanhante do paciente evidenciado no segundo registro de C2, no segundo de C7, no primeiro e segundo registros de C9. Fica claro que o contato ocorreu por iniciativa do paciente, e, assim sendo, pode-se questionar se ele ocorreria caso essa iniciativa do paciente não existisse. 
Observou-se também a presença de conversas técnicas, ou seja, com o objetivo de obter informações sobre o tratamento, a evolução do quadro, ilustrado pelo segundo registro de C5 e de C6. Em apenas um momento, terceiro registro de C7, observou-se o tipo de conversa técnica associada a tentativa de descontrair o paciente, onde os técnicos e auxiliares de enfermagem expressaram um sorriso.

Entende-se que o respeito no relacionamento implica em primeiramente saber respeitar as pessoas em todos os níveis, talento para falar na hora certa e simpatia para manter o respeito e o bom humor (MEDEIROS, 2005). Afinal a qualidade de um serviço assistencial está diretamente associada à qualidade da relação interpessoal que ocorre entre os pacientes e os profissionais encarregados da assistência.

\section{Observações do Hospital psiquiátrico}

Paciente 49: O auxiliar de enfermagem teve contato com a paciente três vezes, sendo duas por iniciativa própria e uma por iniciativa do paciente.

- A paciente pergunta para a auxiliar de enfermagem se ela estava feliz, ela respondeu que sim e que estava pensando alto.

- Outra auxiliar de enfermagem passou e a paciente perguntou se estava desfilando, ela respondeu que não.

- A paciente entrou para atendimento médico e na sala estava a auxiliar de enfermagem que ajudou ao atendimento médico ajudando a dar as informações sobre o paciente.

Paciente 50: O auxiliar de enfermagem teve contato com a paciente cinco vezes, todas por iniciativa própria.

- A paciente saiu do consultório nervosa, derrubando a cama e chorando. Uma auxiliar veio depressa e a segurou dizendo para ela se acalmar. Outra auxiliar veio e a levou para uma sala para se acalmar. Ela não se acalmou, derrubou outra cama e mais uma auxiliar veio ajudar acalmá-la, conversando com ela. O médico também estava presente. Auxiliar saiu e deixou a paciente somente com o médico.

- Auxiliar chegou na porta do quarto, olhou e deixou a porta semicerrada e saiu. 
- Paciente correu atrás do médico, uma auxiliar observou, o médico chegou perto, chamou-a para conversar e explicou-lhe que ela precisa tomar os remédios nas horas certas.

- A paciente estava sentada e uma auxiliar chegou, brincou com ela e disse que ela não precisava ficar nervosa. A paciente perguntou se iria tomar injeção e a auxiliar disse que não pois ela já estava calma.

- A auxiliar veio buscar a paciente para a T. O., ela não queria ir, a auxiliar a abraçou e a convenceu a ir.

Paciente 51: A técnica de enfermagem entrou em contato com a paciente uma vez, por iniciativa própria.

- A técnica de enfermagem veio, verificou a pressão arterial de algumas pacientes, chamou-as pelo nome, veio uma por um.

Paciente 52: O técnico ou o auxiliar de enfermagem não entrou em contato com a paciente

Paciente 53: O técnico ou o auxiliar de enfermagem não entrou em contato com a paciente

Paciente 54: O auxiliar de enfermagem entrou em contato com a paciente duas vezes, por iniciativa própria.

- Auxiliar de enfermagem conversou com paciente, ela estava com hematomas nas pernas, auxiliar estava vigiando para ela não juntar com as outras pacientes que ela estava brigando, ela tentou acalmá-la e permaneceu por mais ou menos quinze minutos, auxiliar foi muito calma com ela.

- Auxiliar veio procurar paciente para consultar, chamou-a pelo nome, ela estava sem sapato, auxiliar pegou, jogou no chão, paciente respondeu que ela foi malcriada com ela.

Paciente 55: A auxiliar de enfermagem entrou em contato com a paciente uma vez por iniciativa própria.

- A auxiliar de enfermagem chamou a paciente para verificar a pressão arterial, ela falou que estava boa, e a paciente saiu.

Paciente 56: A paciente foi para a T.O., fez alguns trabalhos e voltou para a enfermaria. A auxiliar de enfermagem teve contato com o paciente quatro vezes, sendo uma por iniciativa própria e três por iniciativa do paciente.

- A auxiliar de enfermagem chamou a paciente e a abraçou, depois saiu. 
- A paciente foi no posto de enfermagem e pediu para uma funcionária arrumar um cigarro para ela. A auxiliar não deu atenção.

- A paciente voltou no posto de enfermagem e pediu para a funcionária arrumar um cigarro para ela. A funcionária disse que agora não tinha. A paciente voltou para o quarto.

- A auxiliar de enfermagem estava conversando com outra funcionária, a paciente chegou, elas continuaram conversando e não deram atenção a ela. Uma funcionária saiu e a outra foi para o posto de enfermagem, a paciente foi atrás pedindo cigarro e nenhuma funcionária respondeu. Ela pediu de novo e uma auxiliar pegou um cigarro para ela.

Paciente 57:- O técnico ou o auxiliar de enfermagem não entrou em contato com o paciente.

Paciente 58: O técnico ou o auxiliar de enfermagem não entrou em contato com o paciente.

Paciente 59: O técnico ou o auxiliar de enfermagem não entrou em contato com o paciente.

Paciente 60: O técnico ou o auxiliar de enfermagem não entrou em contato com o paciente.

Paciente 61: O técnico ou o auxiliar de enfermagem não entrou em contato com o paciente.

Paciente 62: A auxiliar de enfermagem teve contato com o paciente uma vez, por iniciativa própria.

- O auxiliar de enfermagem chegou próximo do paciente, olhou e saiu.

Paciente 63::A auxiliar de enfermagem teve contato com o paciente uma vez, por iniciativa própria.

- O auxiliar de enfermagem olhou e saiu

Paciente 64: A auxiliar de enfermagem teve contato com o paciente uma vez por iniciativa do paciente. 
- Paciente confuso procurou a enfermeira para conversar, brincou, a enfermeira continuou a brincadeira do paciente que pedia café e queria dar dinheiro, e este saiu. A enfermeira perguntou se estava tudo certo este respondeu que sim e saiu.

Paciente 65: A auxiliar de enfermagem teve contato com o paciente uma vez por iniciativa própria.

- O auxiliar de enfermagem chegou próximo do paciente, olhou e saiu.

Paciente 66: A auxiliar de enfermagem teve contato com o paciente uma vez por iniciativa do paciente.

- O paciente apontou para o frasco de medicação e o auxiliar de enfermagem reconheceu-o dando ao paciente mais uma dose do medicamento para funcionar o intestino. O paciente disse que não estava urinando, o auxiliar disse para ele tomar bastante líquido.

Paciente 67: O técnico ou o auxiliar de enfermagem não entrou em contato com o paciente.

Paciente 68: O técnico ou o auxiliar de enfermagem não entrou em contato com o paciente.

Paciente 69: A auxiliar de enfermagem teve contato com o paciente duas vezes, por iniciativa própria.

- Paciente gritou com o outro paciente, ficou agitado, o auxiliar de enfermagem o pegou pelo braço e saiu levando- o para o quarto.

O paciente retornou ao pátio ainda nervoso, outro auxiliar de enfermagem veio conversar com ele, perguntando o que tinha acontecido, o paciente relatou que o outro paciente estava chamando-o de bandido e que ele não estava fazendo nada mas não queria ser chamado assim. $\mathrm{O}$ auxiliar de enfermagem pediu para ele ficar calmo, que o outro não estava bem e para ele evitar ficar próximo deste paciente. Continuou pedindo para ele ficar calmo, não ficar nervoso e saiu.

Paciente 70: A auxiliar de enfermagem teve contato com o paciente uma vez.

- O auxiliar de enfermagem se aproximou do paciente, observou-o, não verbalizou nada e saiu.

Paciente 71: A auxiliar de enfermagem teve contato com o paciente uma vez, por iniciativa própria. 
- O auxiliar de enfermagem se aproximou do paciente brincando com o mesmo, dizendo que estava chique, que era bonzinho, e saiu.

Paciente 72: O técnico ou o auxiliar de enfermagem não entrou em contato com o paciente.

Quadro 17 Síntese das observações realizadas na clínica psiquiátrica.

\begin{tabular}{|c|c|c|}
\hline Pacientes & Freqüência & Motivo do Contato \\
\hline 49 & 3 vezes & pcte fez contato(2 vezes), auxiliar inform \\
\hline 50 & 5 vezes & $\begin{array}{l}\text { Acalmar pcte, observação (2 vezes), } \\
\text { Brincar com pcte, levar para T.O. }\end{array}$ \\
\hline 51 & $1 \mathrm{vez}$ & Verificar ssvv \\
\hline $\begin{array}{l}52,53,57,58,59 \\
60,61,67,68,72\end{array}$ & 0 & ------- \\
\hline 54 & 2 vezes & Diálogo e acalmar, buscar p/ consulta \\
\hline 55 & $1 \mathrm{vez}$ & Verificar ssvv \\
\hline 56 & 4 vezes & $\begin{array}{l}\text { Chamou e abraçou, pcte fez contato } \\
\text { (3 vezes) }\end{array}$ \\
\hline 62 & 1 vez & Observação \\
\hline 63 & $1 \mathrm{vez}$ & Observação \\
\hline 64 & 1 vez & Pcte fez contato \\
\hline 65 & $1 \mathrm{vez}$ & Observação \\
\hline 66 & $1 \mathrm{vez}$ & Pcte procurou medicação \\
\hline 69 & 2 vezes & Contato físico e conversa $\mathrm{p} / \mathrm{acalmar}$ \\
\hline 70 & $1 \mathrm{vez}$ & Observação \\
\hline
\end{tabular}




\begin{tabular}{|l|l|l|}
\hline 71 & $1 \mathrm{vez}$ & Brincar com pcte \\
\hline
\end{tabular}

No caso da clínica psiquiátrica deveria ocorrer uma predominância de técnicas ou habilidade de relacionamento interpessoal, relação de ajuda, comunicação e interação entre duas pessoas, uma vez que há aquela que necessita de ajuda e outra que deveria se dispor a ajudá-la. Isso não quer dizer que outras técnicas sejam exclusivas da clínica psiquiátrica, elas podem e devem ser aplicadas em todas as clínicas ou especialidades, mas é através destas que os técnicos e auxiliares de enfermagem se baseiam para obter informações mais precisas sobre a melhora e a recuperação do paciente, ou a regressão do quadro mental, para transmitir os dados obtidos ao enfermeiro e à equipe multiprofissional.

O quadro mostra que dos vinte e quatro pacientes, dez deles não tiveram nenhum tipo de abordagem pelos técnicos e auxiliares de enfermagem (P52, P53, P57, P58, P59, P60, P61, P67, P68 e P72), e nos outros, observa-se uma freqüência muito baixa deste contato. Evidencia-se também que mesmo ocorrendo o contato, em quatro pacientes (P62, P63, P65 e P70) este se restringiu apenas à observação, sem nenhum diálogo. Com apenas três pacientes, (P54, P56 e P69), ocorreu uma abordagem mais terapêutica, com objetivo de ajudá-los, apresentando situações de diálogo ou demonstração de afeto, como um abraço.

Observou-se também que nos pacientes denominados P49, P56, P64, e P66, o contato que existiu partiu dos próprios pacientes, ou seja, não foi uma iniciativa dos técnicos e auxiliares de enfermagem.

Diante desses resultados constata-se o quanto está deficiente, precária e até desumana a assistência aos pacientes psiquiátricos observados no presente estudo. 
Não se pode ajudar um paciente se não se aproxima dele, se não existem momentos de interação, pois entende-se que é através do relacionamento interpessoal que se procura atender suas necessidades. Silva et al. (2001), consideram que o cuidado de enfermagem está associado à satisfação das necessidades do paciente, à promoção de seu bem estar, e ainda que, o cuidado de enfermagem, é permeado pela relação interpessoal estabelecida entre enfermagem e paciente.

Revela-se assim, o quanto o discurso da humanização está apenas na intenção e distante da ação. Os profissionais de enfermagem, principalmente que trabalham com pacientes psiquiátricos, deveriam ter habilidades centradas no relacionamento interpessoal, na comunicação terapêutica, necessidades estas primordiais e essenciais para ajudar o paciente a sair da crise. Certamente, a atitude terapêutica deve e precisa ter lugar nas ações do cuidado. Este estudo mostra a necessidade de se repensar a formação dos técnicos e auxiliares de enfermagem, bem como, do enfermeiro.

Avaliar seu desempenho durante o contato com a pessoa que requer ajuda, é um hábito que a enfermagem não tem desenvolvido. Entretanto, este revertese de inúmeras oportunidades para adequação do seu procedimento técnico, tendo em vista as conseqüências benéficas para o outro (RIBEIRO et al., 2003).

Sabe-se que o relacionamento é um desafio constante, mas pode-se ajudar e ajudar o próximo. Melhorar o julgamento sobre si mesmo e sobre outras pessoas auxilia na compreensão do relacionamento humano, pois promove a autoanálise (MEDEIROS, 2005). 


\section{7- CONCLUSÕES}

Independente da clínica onde foram realizadas as entrevistas ou observações, notou-se que apesar dos pacientes relatarem que são bem tratados o conteúdo de suas falas não são convincentes no sentido de que essas ocorrem da forma como relatam, o que leva ao entendimento de que eles tem medo de serem mal tratados, de ter contato com pessoal sem educação, medo de ofender, e até mesmo de reclamarem seus direitos de uma boa assistência de saúde, além de oferecerem poucas sugestões que poderiam contribuir para melhorar seu tratamento. Importante considerar também que, nesta cidade, estes são os únicos hospitais que acolhem estes pacientes quando necessitam de cuidados à sua saúde e isso reafirma o fato deles não trazerem a realidade nos conteúdos de suas falas.

As conversas que ocorreram, foram classificadas como sendo de breve duração, superficiais, mecânicas, descompromissadas, na maioria das vezes com conteúdo relacionados ao tratamento. Constatou-se, assim, uma predominância pelas características do modelo médico, uma preocupação por parte dos técnicos e 
auxiliares de enfermagem em realizarem as técnicas, as medicações e, em manter uma distância do paciente, evitando envolvimentos com estes, deixando evidente que sua formação ainda é predominantemente instrumental (técnica) onde não é incluído, nem como técnica o relacionamento interpessoal.

Ao se utilizar a definição operacional de relacionamento interpessoal com base na descrição de Furegato (1999), este estudo mostrou que esta habilidade foi desenvolvida sempre relacionada com a execução de algum procedimento técnico, não ocorrendo o relacionamento terapêutico, que deve se estabelecer quando os técnicos e auxiliares de enfermagem colocam-se a disposição do paciente com objetivo de ajudá-lo através do diálogo, caracterizando uma relação com início, desenvolvimento e fim.

A afirmativa de Vila (2001) atesta este fato quando descreveu que a equipe de enfermagem percebe o relacionamento entre equipe e paciente de maneira escassa, salientando-o nos momentos de realização de atividades, procedimentos ou rotinas próprias do serviço.

Ficou evidente o despreparo dos técnicos e auxiliares de enfermagem para se comunicarem ou se relacionarem com os pacientes, tendo em vista que estes várias vezes tiveram contato com os pacientes, mas apenas observaram, não dialogando ou quando este era estabelecido ocorria apenas em termos de brincadeiras.

Entretanto, há uma contradição entre os resultados deste estudo em relação àqueles encontrados por (Ribeiro, 2002) quando os técnicos e auxiliares de enfermagem afirmaram que aplicam a técnica de relacionamento interpessoal no exercício de suas atividades profissionais. Além disso, ainda neste estudo, alunos de 
um curso de enfermagem de nível médio afirmaram que aprenderam esta habilidade nos conteúdos das disciplinas estudadas, assim como seus professores também relataram que esta habilidade está presente nos conteúdos de suas disciplinas.

Neste caso, é de difícil compreensão as preocupações e os questionamentos acerca da qualidade e humanização da assistência ao paciente, visto que esses aspectos fazem parte do conteúdo ministrados nos cursos de formação e declarados como apreendidos e aplicados (RIBEIRO, 2002). Assim sendo, existe um distanciamento entre o que se propõe teoricamente, o que é realmente desenvolvido em prática e o que é relatado por aquele a quem é destinado esta habilidade, ou seja, o paciente.

Segundo Matsuda, Évora \& Boan (2000) espera-se que os profissionais de saúde procurassem capacitar-se e efetuar leituras, participar de palestras, ou seja, estudos e exercícios que possibilitassem trabalhar a auto percepção, além de habilidades de comunicação e relacionamento interpessoal para que, na prática, pudessem ter melhor desempenho profissional, entendendo que a enfermagem não pode se ater apenas a parte técnica, mas que os aspectos humanos abordados através do relacionamento interpessoal são também extremamente importantes. Assim, a situação levantada neste estudo nos leva ao entendimento de que torna-se imprescindível o oferecimento de educação continuada em serviço por parte dos hospitais, para desenvolver esta habilidade e aplicá-la com mais facilidade. Trevelbee (1982) reforça a importância da comunicação quando relata que esta afeta ambos os participantes, e a forma de relacionar-se com os outros proporciona satisfação e crescimento pessoais. 
Ficou clara a valorização que os pacientes dão às conversas ocorridas com os técnicos e auxiliares de enfermagem e como estas ajudam em seus tratamentos, despertando sentimentos positivos, apesar destas terem sido tão pouco presentes neste estudo. Mesmo os pacientes não conhecendo a definição de relacionamento interpessoal, temas atribuídos a esta habilidade, assim como de comunicação, foram destacados como importantes para o seu bem estar.

Chamou-nos atenção, que em todas as clínicas envolvidas no estudo, a freqüência do contato com os pacientes foi pequena, e, partindo do princípio de que a pessoa internada é aquela que requer ajuda e atendimento às suas necessidades, levanos a refletir o “caos” em que se encontra a assistência de enfermagem, enquanto pensado numa visão de integralidade, holística e humanizado.

Surpreendentemente a situação encontrada no atendimento da clínica médica e cirúrgica, não difere daquela do hospital psiquiátrico, no qual o relacionamento interpessoal e a comunicação terapêutica, não se constituem apenas a base de referência para assistir o outro, é a própria ação, que associada ao medicamento e ao atendimento de outros profissionais da equipe de saúde, propiciam o tratamento do paciente psiquiátrico.

Esperava-se, assim, observar a aplicação da habilidade de relacionamento interpessoal no horário proposto para a observação dos pacientes, ou seja de quinze às dezessete horas, já que neste período há menos ocorrência de cuidados prescritos como banho, curativo, dieta, atendimentos de equipe multiprofissional; entretanto, aquele que seria um dos momentos apropriados para os técnicos e auxiliares de enfermagem se dedicarem a aplicação da habilidade em questão, não ocorreu. Entende-se, que cabe ao enfermeiro, valorizar quando sua equipe dispensa atenções 
individuais, privilegia o respeito às necessidades dos pacientes, preocupa-se com seu estado e estimula a comunicação entre enfermagem e paciente. No entanto, mesmo com a facilitação do horário, a aplicabilidade da referida habilidade não foi verificada, não sendo constatada também a presença do próprio enfermeiro no sentido de estímulo para que ela ocorresse.

Vila (2001) demonstrou em sua dissertação de mestrado, através de entrevistas realizadas em CTI, que existe a dificuldade da equipe de enfermagem para romper padrões culturais perpetuados e compartilhados pela equipe de saúde como um todo. Apesar destas conceituarem o cuidado humano de forma adequada, os informantes mencionaram atitudes e comportamentos tidos como desumanos e mecânicos, o que ressalta a dicotomia entre a teoria e a prática, e ainda que nem sempre o que é dito é feito, destacando, deste modo, a importância da abordagem humanística e os aspectos científicos para um cuidado de qualidade.

Estes fatos preocupam pois, se a enfermagem busca continuamente uma assistência mais humanizada não somente aos clientes psiquiátricos, mas a todos, o que se vê é uma prestação de cuidados que não valorizam esse aspecto incluindo a falta de atenção por parte da enfermagem, desvalorizando a dignidade humana. Poderia-se, pensar, que estes profissionais de nível médio de enfermagem não estão preparados ou qualificados para a aplicação da habilidade de relacionamento interpessoal? Importante salientar que Trevelbee (1982) já referia que um dos fatores que pode interferir no relacionamento interpessoal seria justamente a falta de treino na execução dessa técnica. Assim, parece-nos ocorrer exatamente isto, ou seja, esses conteúdos mesmo constando em programas de formação dos profissionais dos técnicos e auxiliares de enfermagem, a sua prática exige um treinamento e um 
estímulo contínuo, o que deve ser feito no próprio local de assistência (programas de educação continuada).

Experiências relatadas por Santos \& Reis (2001) em um Curso de Extensão com o tema relacionamento interpessoal e os trabalhadores de saúde com o intuito de fornecer subsídios teóricos, possibilitaram rever noções básicas do Relacionamento Interpessoal como instrumento de assistência e propiciaram melhorias no trabalho em equipe e no atendimento ao paciente.

Como sugestão para elevar a motivação no trabalho de enfermagem foi relatado o "Relacionamento interpessoal" como um aspecto do trabalho que pode ser transformado através de investimentos na área de recursos humanos e de mudanças na política organizacional. O desejo dos profissionais quanto às mudanças merece atenção, pois, proporciona oportunidade para que a motivação do profissional seja refletida no alcance dos objetivos da organização (PEREIRA \& FÁVERO, 2001).

Entende-se que o técnico e o auxiliar de enfermagem bem formados através de uma formação humanística e científica, sejam capazes de dominar a tecnologia, que é mutável, rápida e inconstante. Em compensação, valores como respeito, ética e atenção, devem estar sempre presentes em qualquer relação de pessoas, pois não são mutáveis, nem rápidos ou inconstantes.

Sabe-se o quanto é importante respeitar a individualidade de cada pessoa e o quanto é imprescindível utilizar-se a relação pessoa a pessoa ao lidar-se com indivíduos acometidos por uma doença clínica, cirúrgica, psiquiátrica ou de qualquer outra especialidade. Percebeu-se que todo paciente deseja ser bem tratado, obter atenção e ser valorizado como ser humano. O relacionamento interpessoal pode, sem dúvida, garantir isso a ele. 


\section{REFLEXÕES FINAIS}

Ao pensar em saúde mental deve-se considerar um conjunto de fatores relacionados entre si que, a primeira vista, não parecem problemas de "saúde mental”, mas que influenciam no bem estar das pessoas (DESJARLAIS, 1997). Nesta pesquisa ficou evidente que um dos fatores que mais influenciam no bem estar é o relacionamento interpessoal, daí a importância de seu estudo, aperfeiçoamento e aplicabilidade, principalmente por parte dos auxiliares e técnicos de enfermagem, que tem o privilégio de estar junto ao paciente um período de tempo maior que os outros profissionais da equipe, incluindo o enfermeiro.

Criar integração entre pessoas e grupos só será possível através da aplicação de dinâmicas de relações interpessoais, que favorece o aprendizado do diálogo, e, consequentemente, favorece o entrosamento e o aumento de produtividade no trabalho. Portanto, ao se avaliar a produtividade temos que relacionar a competência dos membros do grupo e suas relações (RIBEIRO, 2002).

A qualidade e a humanização do atendimento estão diretamente ligadas com o efetivo relacionamento interpessoal entre os profissionais de enfermagem e o paciente, pois todas as atitudes do profissional repercutem sobre ele e terão 
significado terapêutico ou não segundo as vivências que despertarão no paciente e nele, profissional (MARTINS, 1996).

Entende-se que o tema desta pesquisa não se esgotou tamanho a complexidade de sua aplicação, mas deseja-se que este possa contribuir para despertar mudanças na assistência prestada pelos serviços de saúde e motivar os técnicos e auxiliares de enfermagem a buscarem continuamente conhecimentos que possam melhorar seu desempenho profissional, contribuir para que ele se sinta motivado a desenvolver, junto ao paciente de qualquer especialidade clínica, a habilidade de relacionamento interpessoal, que certamente vai contribuir muito para a recuperação de sua saúde, uma volta mais rápida à vida ativa e produtiva, e com menor custo aos serviços de saúde de um modo geral.

Por outro lado, é necessário possibilitar às instituições formadoras a reflexão sobre o ensino do relacionamento interpessoal , de forma a proporcionar ao profissional de enfermagem segurança no desenvolvimento desta habilidade, que também é terapêutica e deve associar-se ao tratamento, recuperação e reabilitação do paciente.

Para as instituições de saúde pública e privadas, a contribuição que este estudo pode possibilitar, é no sentido de se buscar a implantação e implementação da educação permanente através da capacitação contínua dos profissionais, como forma das mais importantes, para garantir uma assistência de qualidade, humanizada.

E, finalmente, que as instituições de saúde, tenham um olhar também humanizado para os recursos humanos, pois, não adianta querer que o profissional seja humano no seu relacionamento, quando o próprio ambiente de trabalho e relações humanas são adversas e não motivam o técnico e o auxiliar de enfermagem. 
É preciso cuidar de quem cuida da saúde, pois, muitas vezes, aqueles que cuidam podem estar mais doentes do que os que são cuidados, ou seja, os pacientes; para tanto, é preciso humanizar as práticas de gerenciamento de pessoal. 


\title{
9 REFERÊNCIAS BIBLIOGRÁFICAS
}

\author{
ANGERAMI, E. L. S. \& MENDES, I.A. C. Perspectivas da pesquisa em \\ comunicação em enfermagem. Anais do I SIBRACen, Ribeirão Preto, p. 7- 28, \\ 1988.
}

AQUINO, J. M. de. Relações interpessoais de uma equipe cirúrgica: influências no ambiente de trabalho e na assistência. Salvador, 2000. Dissertação (Mestrado), Escola de Enfermagem, Universidade Federal da Bahia.

BACHION, M. M. Comunicação interpessoal: ensino de algumas habilidades desejadas. Ribeirão Preto, 1994, 141 p. Tese (Doutorado), Escola de Enfermagem de Ribeirão Preto, Universidade de São Paulo - USP.

BECK, C. L. C. A enfermagem fazendo a diferença na vida dos pacientes, através do relacionamento interpessoal. Cogitare Enfermagem, Curitiba, v.2, n.2, p. 52-54, 1997.

BETTINELLI, L. A.; WASKIEVICZ, J. \& ERDMANN, A. L. Humanização do cuidado no ambiente hospitalar. $O$ mundo da saúde. São Paulo, ano 27, v.27, n.2, 2003.

BITTES JUNIOR, A. Cuidando e Des-cuidando: o movimento pendular do significado do cuidado para o paciente. São Paulo, 1996, 106p. Dissertação (Mestrado), Escola de Enfermagem de São Paulo, Universidade de São Paulo - USP.

BOFF, L. Saber cuidar. Petrópolis: Vozes,1999.

CADAH, L. Avaliação da qualidade da assistência de enfermagem sob a ótica da satisfação dos pacientes. São Paulo, 2000, 104p. Dissertação (Mestrado), Escola de Enfermagem de São Paulo, Universidade de São Paulo - USP. 
CATARINO J.; CASSIANO, J. \& SILVA, R. C. O respeito como princípio moral básico e principal princípio em enfermagem. Nursing, n.99, p.21-24, 1996.

CASTILLA DEL PINO, C. Critica a la razon psicopatológica, em Castilla del Pino, C. y Ruiz Vargas, J. M. (eds), Aspectos cognitivos de la esquizofrenia, Trotta, Madrid, p.11-33, 1991.

DANIEL, L.F. A enfermagem planejada. São Paulo: EPU. 1981. 133p.

DESJARLAIS, R. et al. Salud Mental en el mundo: problemas y prioridades en poblaciones de bajos ingresos. Organizacion Panamericana de la Salud. Oficina regional de la Organizacion Mundial de la Salud, 1997.

ERDMANN, A.L. \& PINHEIRO, P. I. G. Gerenciamento do cuidado em enfermagem: questionando estratégias. Cogitare Enfermagem, Revista do departamento de enfermagem da UFPR, v.3, n.1, p.89-96, 1998.

FERRAZ, C. A. Trabalho em equipe. Ribeirão Preto, EERP-USP, p.1-8, mimeografado, 1982.

FUREGATO, A.R.F. - Relações interpessoais terapêuticas na enfermagem. Ribeirão Preto, S.P.: Scala. 1999.

GATTÁS, M. L. B. Relacionamento Interpessoal enfermeiro-paciente. Rev. Paulista de Enfermagem, São Paulo, v.4, n.2 p. 59-61, 1984.

GIL, A C. Métodos e técnicas de pesquisa social. $4^{\text {a }}$ ed. São Paulo: Atlas, 1994.

GILIOLI, M. G. A integração docente-assistencial e o processo ensinoaprendizagem na perspectiva dos docentes. São Paulo, 2000, 128p. Dissertação (Mestrado), Escola de Enfermagem da Universidade de São Paulo USP.

GIOVANI, C. huna e Holismo ( mente-corpo-espírito). [online]. Disponível: http// www.medonline.com.br. [capturado em 10 de agosto de 2005].

GUIMARÃES C. A. O novo paradigma ecológico-holísitco. [online]. Disponível: http//www.geocitiesyahoo.com.br. [capturado em 10 de agosto de 2005].

KAPLAN, H.I.; SADOCK, B.J.; GREEB, J.A. Compêndio de Psiquiatria. Porto Alegre; Artes Médicas, 1997.

KREUTZ, I. O trabalho em equipe de enfermagem. São Paulo, 1993. Dissertação (Mestrado), Escola de Enfermagem da Universidade de São Paulo USP.

LALANDA, P. A interação enfermeiro-paciente. Uma abordagem bioantropológica. Nursing, v.8, n.88, p. 28-32, 1995. 
LUQUE, R.;VILLAGRAN, J.M. Modelos Teorias y paradigmas. In: LUQUE, R.;VILLAGRAN, J.M. Psicopatologia descritiva: nuevas tendencias. Editorial Trotta, Madrid, 2000, p. 39-73.

MACHADO, A. R. R. M.; TAKAMATSU, C. T. \& FILOCRE, J. A questão da avaliação nos ciclos de formação básica plano de estudo sobre avaliação da aprendizagem. Documento da Secretaria da Educação do Estado de Minas Gerais. Projeto piloto de inovação curricular e capacitação de professores do segundo ciclo de formação básica da rede estadual, Belo Horizonte, 1998.

MADEIRA, C. G.; JORGE, S. A.; KAKEHASHI, S.; OLIVEIRA, I. de. Saúde e educação: cursos alternativos para desenvolvimento do pessoal de enfermagem. Rev. Esc. Enfermagem USP. 30 (2), p. 217-28, 1996.

MANZOLLI, M. C. Relacionamento em enfermagem. Aspectos psicológicos. São Paulo: Sarvier, 1983

MATSUDA, L. M.; ÉVORA, Y. D. M. \& BOAN, F. S. O foco no cliente no processo de atendimento de enfermagem: visão dos enfermeiros. Nursing, n. 29, p. 16-20,2000.

MARTINS, M. C. F. N. Relação profissional - paciente: subsídios para profissionais de saúde. Bol. Psiquiátrico, v. 29, n.1, p. 14-22, 1996.

MATOS, E. T. Relação ensino/prestação de cuidados. Nursing, n. 95, p. 9 - 11, 1995.

MEDEIROS, L. Relacionamento interpessoal. CIPA, p.78-9, abril, 2005.

MINAYO, M. C. S. O desafio do conhecimento: pesquisa qualitativa em saúde. São Paulo: Hucitec, 2000.

MIRANDA, F.A.N.; RODRIGUES, A.R.F.; SCATENA, M.C.M. - Relacionamento Interpessoal focalizando o elemento surpresa numa interação. Nursing, n. 101, p. 3034, 1996.

MOSCOVICI, F. Renascença organizacional. 3ed. Rio de Janeiro, José Olympio, 1993.

NAKAO, J. R. S. Assistência de enfermagem: modalidade-trabalho de equipe. Revista Paulista de Hospitais, v. 33, n. 3-4, p. 68-70, 1985.

PEPLAU, H. E. Relaciones interpessonales en enfermeria. Barcelona. Ed. Científica y Técnica. 1952.

PEREIRA, L. L. Vivenciando a comunicação como descoberta. São Paulo, 1999, 116p. Tese (Doutorado), Escola de Enfermagem da Universidade de São Paulo. 
PEREIRA, M.C.A. \& FÁVERO, N. A motivação no trabalho da equipe de enfermagem. Revista Latino Americana Enfermagem, p. 7-12, 2001

PIAGGE, C. D. A tensão entre o cuidar técnico e humano. Um estudo das representações sociais da relação enfermeiro-paciente. São Paulo, 1998, 93p. Tese (Mestrado), Escola de Enfermagem da Universidade de São Paulo USP.

PIROLO, S. M. A equipe de enfermagem e o mito do trabalho em grupo. São Paulo, 1999, 188p. Dissertação (Mestrado), Escola de Enfermagem de São Paulo da Universidade de São Paulo, USP.

RIBEIRO, M. I. L. C. \& PEDRÃO, L. J. Relacionamento Interpessoal em enfermagem: Considerações sobre a formação/atuação no nível médio de enfermagem. Paidéia, Cadernos de Psicologia e Educação, Departamento de Psicologia e Educação, FFCLRP-USP, 11(20), p. 99-102, 2001.

RIBEIRO, M. I. L. C. Relacionamento Interpessoal no nível médio de Enfermagem. Ribeirão Preto, 2002, 97p. Dissertação (Mestrado), Escola de Enfermagem de Ribeirão Preto, Universidade de São Paulo - USP.

RIBEIRO, M. I. L. C. \& FUREGATO, A R. F. Reflexões sobre a importância do Relacionamento Interpessoal na formação de profissionais de Enfermagem. Nursing, n. 6, v.66, p.19-24, 2003.

RIBEIRO, M. I. L. C., MIYASAKI, S. C. S., FUREGATO, A. R. F. \& SCATENA, M. C. M. Experiência de interação de ajuda com dois alunos de enfermagem. Revista Baiana de enfermagem, Salvador, v.18, p.67-74, 2003.

RODRIGUES, A. R. F. Enfermagem psiquiátrica-saúde mental: prevenção e intervenção. São Paulo, Hucitec, 1996, 158p.

Pensando sobre o relacionamento enfermeira-paciente. São

Paulo, Rev. Paul. Enfermagem, no 10, vol. 1, p. 38-40, 1991.

ROGERS, C. R. \& ROSEnBERG, R. L. A pessoa como centro. São Paulo: EPU, 1997.

ROGERS, C. R. Liberdade para aprender. Interlivros, 1978.

RUDIO, F. V. Orientação não-diretiva na educação, no aconselhamento e na psicoterapia. Petrópolis, Vozes, 1990.

SADALA, M. L. A. \& STEFANELLI, M. C. Avaliação do ensino de relacionamento enfermeira-paciente. Rev. Latino-americana de enfermagem, v.4, p. 139-51, 1996.

SANTIAGO, M. M. A.; LOPES, G. T. \& CALDAS, N.P. Educação em Enfermagem através da REBEn: 1990-2001. Revista Brasileira de Enfermagem, Brasília, v.55, p. 336-343, 2002. 
SANTOS, A. M. L. \& REIS, O. E. A dinâmica das relações interpessoais no cotidiano de trabalho da equipe de saúde e a problemática da dependência química. O mundo da saúde, São Paulo, ano 25, v.25, p. 277-280, 2001.

SAWADA, N.O; GALVÃO, C. M.; CORNIARI, F.; CASTRO, A P. As necessidades interpessoais do enfermeiro líder no contexto hospitalar. $7^{\circ}$ Simpósio de Comunicação, Ribeirão Preto, p.13-7, 2000.

SILVA, S. C. A visão da enfermagem frente novos paradigmas - reflexão teóricas. Nursing, n. 13, p. 17-19, 1999.

SILVA, L. F., DAMASCENO, M. M. C., CARVALHO, C. M. L. \& SOUZA, P. D. S. Cuidado de enfermagem: o sentido para enfermeiros e pacientes. R. Bras. Enferm., Brasília, v.54, n.4, p. 578-588, 2001.

SILVA, L.F. da et al. Cuidado de enfermagem: o sentido para enfermeiros e pacientes. R. Bras. Enferm., Brasília, v.54, n.4, p.578-588, 2001.

SOUZA, C. A. C. O ensino de saúde mental aplicado à enfermagem - o relacionamento interpessoal e a comunicação. In: SIMPÓSIO BRASILEIRO DE COMUNICAÇÃO EM ENFERMAGEM, 2ª 1990, Ribeirão Preto. ANAIS do SIBRACEn, Ribeirão Preto: EERP-USP, 1990. p. 599-609.

SOUZA, M. L., REIBNITZ, K. S. \& HORR, L. Educação profissional de nível médio em enfermagem: necessidades e perspectivas. Texto e Contexto Enfermagem, Florianópolis, v. 6, n. esp., p. 85-112, 1997.

STUART, G.W.; LARAIA, M.T. Enfermagem Psiquiátrica - princípios e práticas. Porto Alegre, Artemed Editora, 2001.

STUTZ, B. L. Técnico de enfermagem: o perfil traçado pôr profissionais da área. Rev. Bras. Enferm., Brasília, v. 52, n. 4, p. 606-614, 1999.

TAKAHASHI, R. T. \& FERNANDES, M. F. P. Percepção dos licenciados de enfermagem sobre a disciplina metodologia de ensino em enfermagem. Nursing, n.41, p. 30- 4, 2001.

TEIXEIRA.H. Holismo e medicina. [online]. Disponível: http// www.medionline.com.br [capturado em 10 de agosto de 2005].

TRAVELBEE, J. Intervencion en enfermeria psiquiátrica. Colômbia, Carvajal, 1982, 282p.

TRIVIÑOS, A. N. S. Introdução á pesquisa em ciências sociais: a pesquisa qualitativa em educação. São Paulo, Atlas, 1994, 175 p.

VICTORA, C. G., KNAUTH, D. R. \& HASSEN, M. N. .A Peqquisa qualitativa em Saúde. Uma introdução ao tema. Porto Alegre: Tomo Editorial, 2000, 136p. 
VILA, V. S. C. O significado cultural do cuidado humanizado em Unidade de Terapia Intensiva: muito falado e pouco vivido. Ribeirão Preto, 115p., 2001.

WALDOW, V.R. - Cuidado humano. O resgate necessário. Porto Alegre: Sagra Luzzatto, 1998.

WOLFF, L. D. G.; GONÇALVES, L. S. \& YEDE, S. B. Cuidar / Cuidado: elementos e dimensões na perspectiva de pessoas internadas em hospital de ensino. Cogitare Enfermagem, Revista do departamento de enfermagem da UFPR, v.3, n.1, p.32- 39, 1998. 


\section{APÊNDICES}

\section{APÊNDICE 1}

\begin{tabular}{|l|}
\hline \multicolumn{1}{|c|}{ ROTEIRO DE ENTREVISTA SEMI-ESTRUTURADA COM O } \\
PACIENTE
\end{tabular}




\section{APÊNDICE 2}

\section{Termo de Consentimento Livre e Esclarecido (Pacientes)}

Sou enfermeira, trabalhei durante dez anos em hospitais como chefe de unidade e supervisora, hoje ensino no curso de Técnico em Enfermagem e estou fazendo outro curso, o Doutorado, onde vou desenvolver uma pesquisa. Quero estudar o relacionamento dos técnicos e auxiliares de enfermagem com os pacientes internados, e pretendo saber o que os pacientes entendem sobre esta relação, como ela acontece, o motivo que os levou a esta interação e como eles valorizam este relacionamento.

Para isto, contarei com a ajuda de três alunos um curso de Técnico em enfermagem que vão observar e anotar durante duas horas em uma tarde de que forma os auxiliares e técnicos de enfermagem atendem aos pacientes internados. Serão feitas também algumas perguntas para completar o estudo, sendo que suas respostas serão gravadas.

Os resultados desse estudo serão importantes para melhorar, no hospital, o atendimento das pessoas que necessitam, e também para melhorar o ensino dos estudantes de Enfermagem, por isso, posteriormente, deverão ser divulgados em eventos científicos e publicados em revistas específicas da área da saúde.

Você participa se estiver de acordo. Não haverá gastos, desconfortos e nenhum prejuízo a você, como nenhuma remuneração por sua participação. Poderá solicitar esclarecimentos a qualquer momento, e se quiser entrar em contato com a pesquisadora o telefone está anotado abaixo. Se desejar poderá desistir de participar sem que o seu tratamento seja interrompido. Posso garantir que todas as informações colhidas serão respeitosamente utilizadas para essa pesquisa, e que seu nome não será identificado. Caso concorde em participar, preencha seus dados pessoais:

Nome: RG:

Assinatura: Data:

Enf ${ }^{\text {a }}$ Pesquisadora: Maria Inês Lemos Coelho Ribeiro RG: M-3.068.286 COREn: MG-48560

Endereço: R. Noruega n ${ }^{0} 38$ - Bairro Novo Mundo - Passos-MG Tel.: 3522-1632 


\section{APÊNDICE 3}

\section{Termo de Consentimento Livre e Esclarecido (Enfermagem)}

Sou enfermeira, trabalhei durante dez anos em hospitais como chefe de unidade e supervisora, hoje ensino no curso de Técnico em Enfermagem e estou fazendo outro curso, o Doutorado, onde vou desenvolver uma pesquisa. Quero estudar o relacionamento dos técnicos e auxiliares de enfermagem com os pacientes internados, e pretendo saber o que os pacientes entendem sobre esta relação, como ela acontece, o motivo que os levou a esta interação e como eles valorizam este relacionamento.

Para isto, contarei com a ajuda de três alunos do curso de Técnico em Enfermagem que vão observar e anotar durante duas horas em uma tarde de que forma os auxiliares e técnicos de enfermagem atendem os pacientes internados.

Gostaria de pedir a sua colaboração, pois, os resultados desta pesquisa serão importantes e poderá contribuir tanto na melhoria do ensino de enfermagem como na assistência prestada ao cliente. Serão também publicados em revistas e apresentados em congressos.

Você participa se estiver de acordo. Asseguro que não haverá riscos, desconfortos, gastos ou prejuízos de qualquer natureza, como também nenhuma remuneração por sua participação. Poderá solicitar esclarecimentos quando necessário no endereço e telefone que está anotado abaixo, além de se retirar do estudo em qualquer momento, sem que haja penalização. Posso garantir que todas as informações colhidas serão respeitosamente utilizadas e assegurar que você não será identificado com seu nome.

Caso concorde preencha seus dados pessoais:

Nome:

Identidade: Data:

Assinatura:

Enf ${ }^{\text {a }}$ Pesquisadora: Maria Inês Lemos Coelho Ribeiro Identidade: M-3.068.286 Coren: MG 48.560

Endereço: Rua Noruega no 38 - Bairro Novo Mundo - Passos-MG Telefone: 3522-1632 
11 ANEXO 


\section{ANEXO 1}
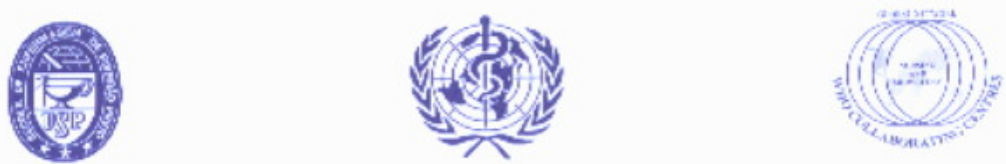

ESCOLA DE ENFERMAGEM DE RIBEIRÃO PRETO - UNIVERSIDADE DE SÃO PAULO

CENTRO COIABORADOR DA ORGANIZACÁO MLINDLAL DA SAÚDE PARA

O DESENVOLVMMENTO DA PESQUISA EM ENFERMAGEM

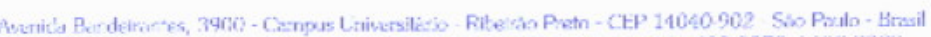

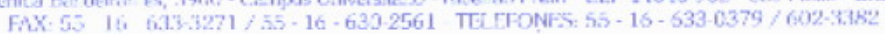

COMITÊ DE ÉTICA EM PESQUISA DA EERP/USP

Of.CEP-EERP/USP - 007/2005

Ribeiråo Preto, 17 de janeiro de 2005

Prezado Senhor,

Comunicamos que o projeto de pesquisa, abaixo especificado, foi analisado e considerado APROVADO AD REFERENDUM do Comitê de Ética em Pesquisa da Escola de Enfermagem de Ribeirāo Preto da Universidade de Săo Paulo, em 17 de janeiro de 2005

Protocolo:

$n^{0} 0503 / 2004$

Projeto:

O Relacionamento Interpessoal: uma visão dos Pacientes e Equipe de Enfermagem

Pesquisadores: Luiz Jorge Pedrăo (Orientador)

Maria Inês Lemos Coelho Ribeiro (Doutoranda)

Em atendimento à Resolução 196/96, deverá ser encaminhado ao CEP o relatório final da pesquisa e a publicaçăo de seus resultados, para acompanhamento, bem como comunicada qualquer intercorrência ou a sua interrupçăo.

Atenciosamente,

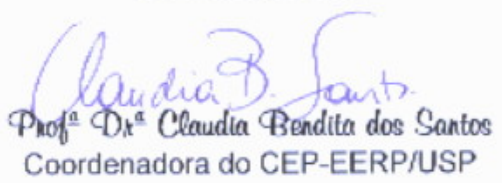

Ilmo. Sr.

Prof. Dr. Luiz Jorge Pedrão (Orientador)

Departamento de Enfermagem Psiquiátrica e Ciências Humanas

Escola de Enfermagem de Ribeirão Preto-USP 